$$
\begin{array}{cl}
\text { Reghie: } & \text { NUREG/CR-4315 } \\
\text { JUL } 05989 & \text { Rol.9 } \\
&
\end{array}
$$

\title{
Evaluation of Nuclear Facility
}

Decommissioning Projects

Summary Status Report

Three Mile Island Unit 2

Radioactive Waste and Laundry Shipments

Prepared by D.H. Doerge, D.R. Haffner

Westinghouse Hanford Company

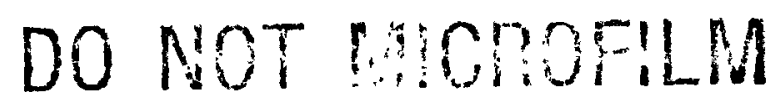

Prepared for

U.S. Nuclear Regulatory

COVER

Commission 


\section{NOTICE}

This report was prepared as an account of work sponsored by an agency of the United States Government. Neither the United States Government nor any agency thereof, or any of their employees, makes any warranty, expressed or implied, or assumes any legal liability of responsibility for any third party's use, or the results of such use, of any information, apparatus, product or process disclosed in this report, or represents that its use by such third party would not infringe privately owned rights.

\section{NOTICE}

Availability of Reference Materials Cited in NRC Publications

Most documents cited in NRC publications will be available from one of the following sources:

1. The NRC Public Document Room, $1717 \mathrm{H}$ Street, N.W. Washington, DC 20555

2. The Superintendent of Documents, U.S. Government Printing Office, Post Office Box 37082 , Washington, DC 20013-7082

3. The National Technical Information Service, Springfield, VA 22161

Although the listing that follows represents the majority of documents cited in NRC publications, it is not intended to be exhaustive.

Referenced documents available for inspection and copying for a fee from the NRC Public Document Room include NRC correspondence and internal NRC memoranda; NRC O ic a of Inspection and Enforcement bulletins, circulars, information notices, inspection and investigation notices; Licensee Event Reports; vendor reports and correspondence; Commission papers; and applicant and licensee documents and correspondence.

The following documents in the NUREG series are available for purchase from the GPO Sales Program: formal NRC staff and contractor reports, NRC-sponsored conference proceedings, and NRC booklets and brochures. Also available are Regulatory Guides, NRC regulations in the Code of Federal Regulations, and Nuclear Regulatory Commission /ssuances.

Documents available from the National Technical Information Service include NUREG series reports and technical reports prepared by other federal agencies and reports prepared by the Atomic Energy Commission, forerunner agency to the Nuclear Regulatory Commission.

Documents available from public and special technical libraries include all open literature items, such as books, journal and periodical articles, and transactions. Federal Register notices, federal and state legislation, and congressional reports can usually be obtained from these libraries.

Documents such as theses, dissertations, foreign reports and translations, and non-NRC conference proceedings are available for purchase from the organization sponsoring the publication cited.

Single copies of NRC draft reports are available free, to the extent of supply, upon written request to the Division of Information Support Services, Distribution Section, U.S. Nuclear Regulatory Commission, Washington, DC 20555.

Copies of industry codes and standards used in a substantive manner in the NRC regulatory process are maintained at the NRC Library, 7920 Norfolk Avenue, Bethesda, Maryland, and are available there for reference use by the public. Codes and standards are usually copyrighted and may be purchased from the originating organization or, if they are American National Standards, from the American National Standards Institute, 1430 Broadway, New York, NY 10018. 


\section{DISCLAIMER}

This report was prepared as an account of work sponsored by an agency of the United States Government. Neither the United States Government nor any agency Thereof, nor any of their employees, makes any warranty, express or implied, or assumes any legal liability or responsibility for the accuracy, completeness, or usefulness of any information, apparatus, product, or process disclosed, or represents that its use would not infringe privately owned rights. Reference herein to any specific commercial product, process, or service by trade name, trademark, manufacturer, or otherwise does not necessarily constitute or imply its endorsement, recommendation, or favoring by the United States Government or any agency thereof. The views and opinions of authors expressed herein do not necessarily state or reflect those of the United States Government or any agency thereof. 


\section{DISCLAIMER}

Portions of this document may be illegible in electronic image products. Images are produced from the best available original document. 

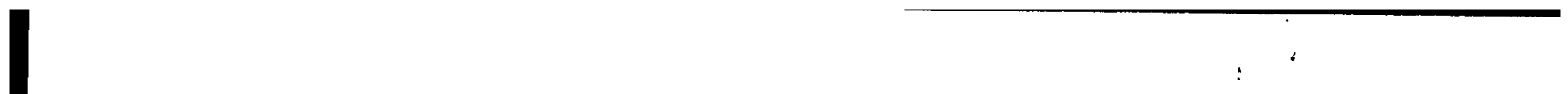


\section{ABSTRACT}

This document summarizes information concerning radioactive waste and laundry shipments from the Three Mile Island Nuclear Station Unit 2 to radioactive waste disposal sites and to protective clothing decontamination facilities (laundries) since the loss of coolant accident experienced on March 28, 1979.

Data were collected from radioactive shipment records, summarized, and placed in a computerized data information retrieval/manipulation system which permits extraction of specific information.

This report covers the period of Apri1 9, 1979 through April 19, 1987. Included in this report are: waste disposal site locations, dose rates, curie content, waste description, container type and number, volumes and weights. This information is presented in two major categories:

protective clothing (laundry) and radioactive waste. Each of the waste shipment reports is in chronological order. 


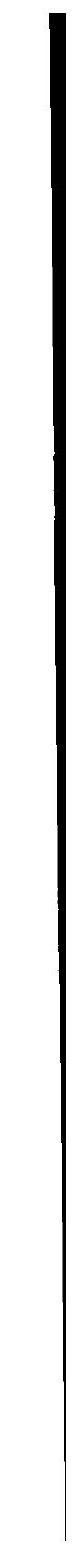


TABLE OF CONTENTS

PAGE

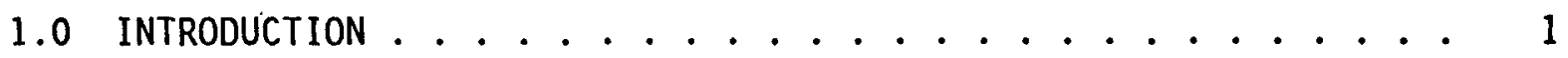

2.0 SUMMARY OF SHIPMENTS ............... 4

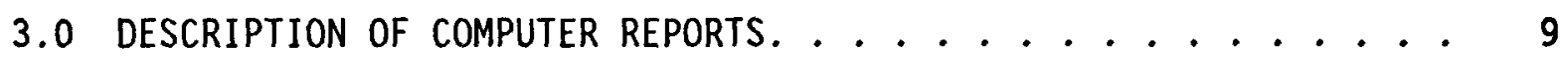

3.1 TMI-2 Acronyms and Abbreviations. .......... 9

3.2 TMI-2 Protective Clothing Notes........... 9

3.3 Waste Shipment Report - Protective Clothing ....... 9

3.4 TMI-2 Radioactive Waste Notes ......... 9

3.5 Waste Shipment Report - Radioactive Waste ....... 9

4.0 COMPUTER REPORTS ................... 10

4.1 TMI-2 Acronyms and Abbreviations. . . . . . . . 10

4.2 TMI-2 Protective Clothing Notes . . . . . 15

4.3 Waste Shipment Report - Protective Clothing . . . . 17

4.4 TMI-2 Radioactive Waste Notes ............ 29

4.5 Waste Shipment Report - Radioactive Waste ....... 32 


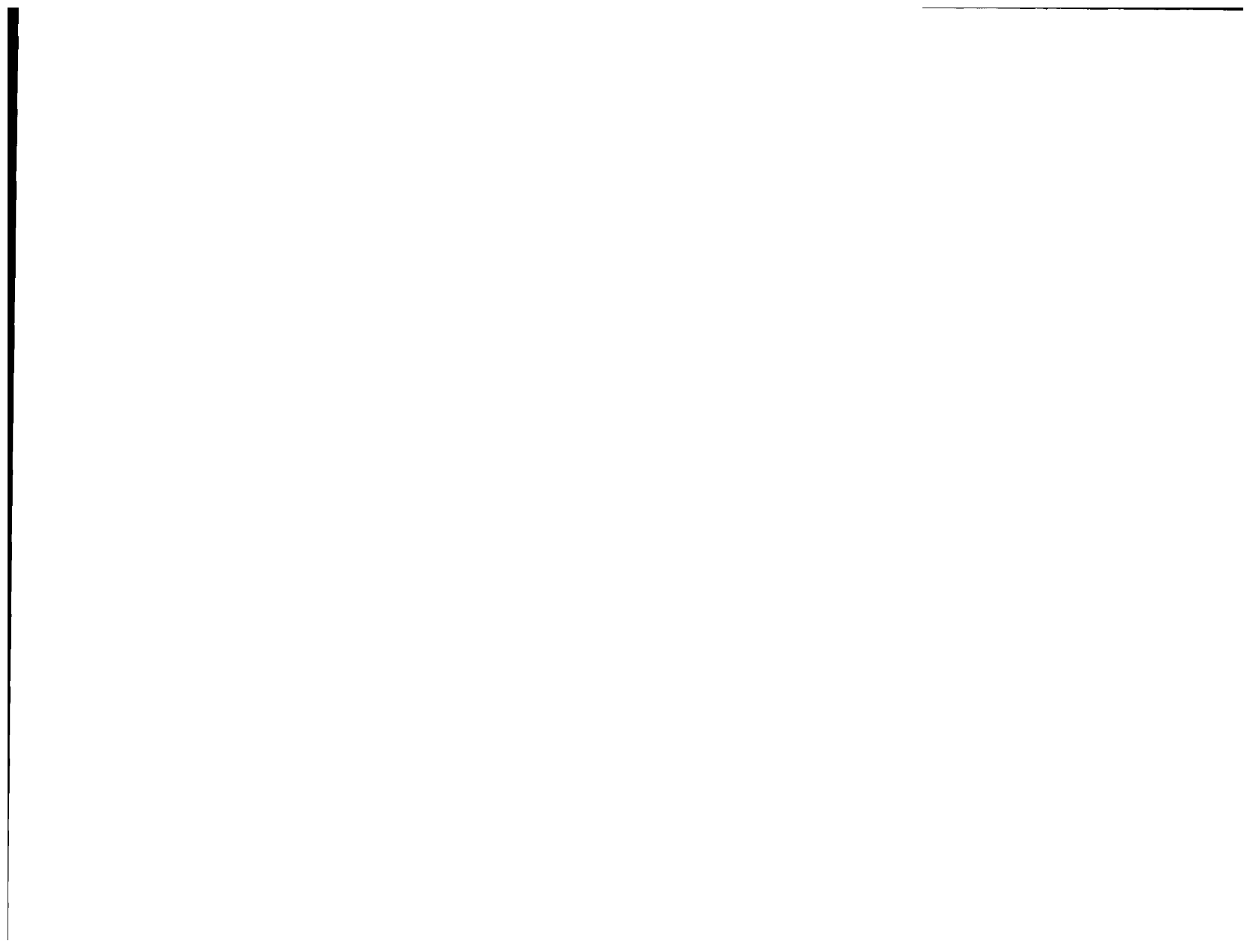
$-$ . .

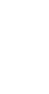
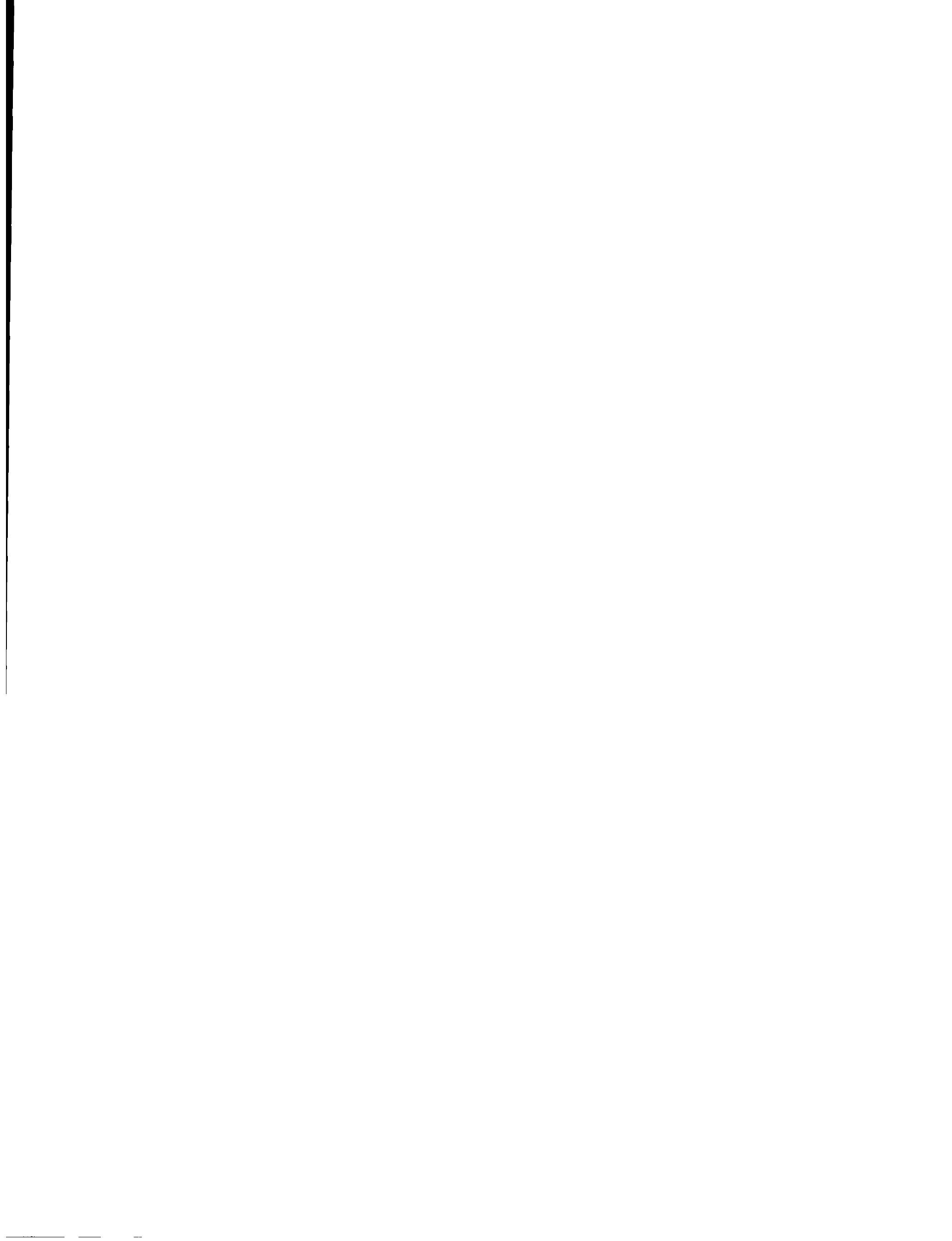


\title{
EVALUATION OF NUCLEAR FACILITY DECOMMISSIONING PROJECTS DEPARTMENT
}

\section{THREE MILE ISLAND UNIT 2}

\author{
Radioactive Waste and Laundry Shipments
}

\subsection{INTRODUCTION}

The Three Mile Island Unit 2 (TMI-2) nuclear power station is located near Middletown, Pennsylvania. TMI-2 is a pressurized water reactor rated at 959 MWe. The reactor began commercial operation on December 30, 1978.

On March 28, 1979, TMI-2 experienced a partial loss of coolant water which exposed the upper portion of the reactor core. Resulting temperatures in the core region were in excess of $2500^{\circ} \mathrm{F}$ causing considerable damage to the core and possibly to other reactor components.

Contaminated reactor coolant water was released to the reactor building basement and to the auxiliary and fuel handling buildings (Figures 1 and 2). This release resulted in gross contamination requiring extensive decontamination and waste handling operations to restore these buildings to a tenantable condition. Decontamination and repair activities have required many labor man-hours and man-rems of exposure.

Because of the vast quantity of data generated during decontamination, equipment recovery and waste handling activities, the U.S. Nuclear Regulatory Commission (NRC) requested that the data be assembled, analyzed, and entered into a computer data base for historical purposes. The information could also serve as a comprehensive base line for future planning, estimates, and actions required should a nuclear facility be confronted with problems similar to those experienced at TMI-2.

Work within the scope of this report is being conducted under the Evaluation of Nuclear Facility Decommissioning Projects (ENFDP) program. The ENFDP program was originated in 1981 under the auspices of the NRC Office of Nuclear Regulatory Research and is currently administered through its Division of Engineering.

The Office of Surplus Facilities Management, a department within UNC Nuclear Industries (UNC) at the Hanford Site, was designated technical director of the program with responsibility for data collection, analysis, documentation, and evaluation of decommissioning projects. See NUREG/CR-2522, "Evaluation of Nuclear Facility Decommissioning Projects Program Plan," for a complete description of the program.

In June 1987, with consolidation of the Hanford contractors, Westinghouse Hanford Company assumed responsibility for the UNC portion of the Hanford Operations and Engineering Contract, including the ENFDP program. 
THREE MILE ISLAND UNIT 2

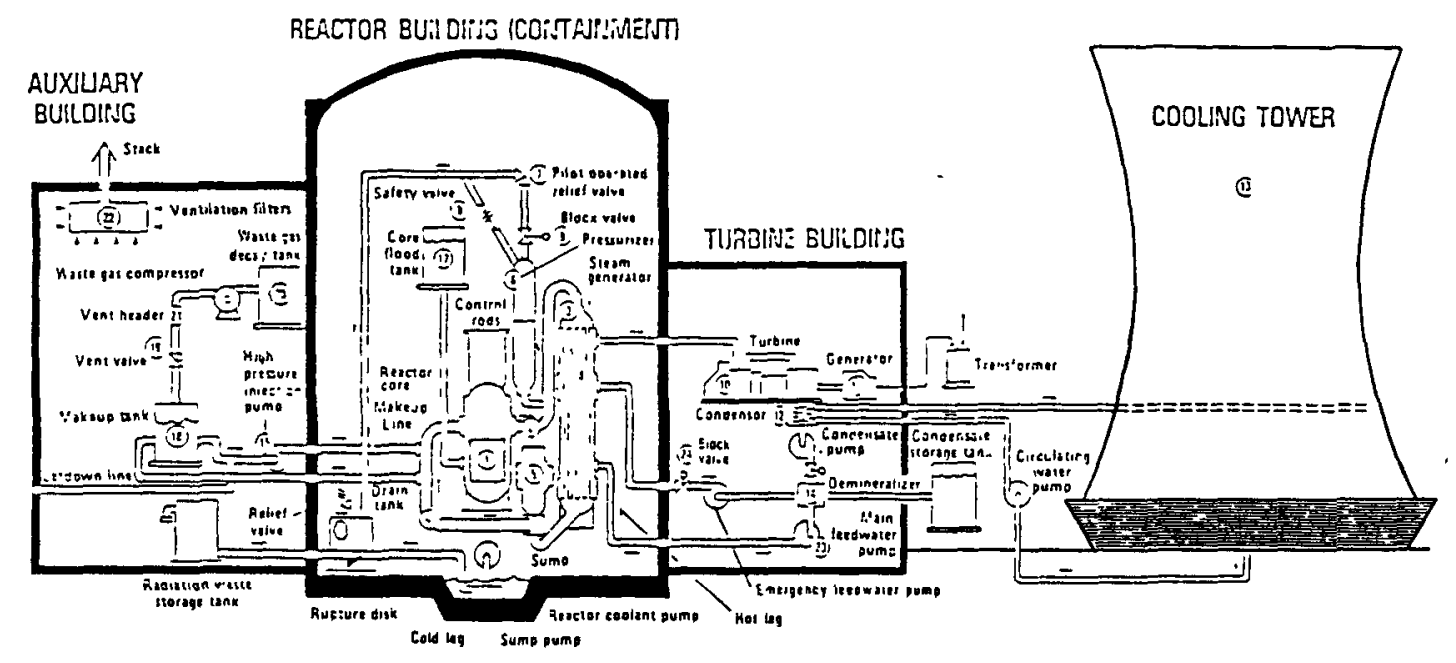

Figure 1. Reactor \& Auxllary Buildings.

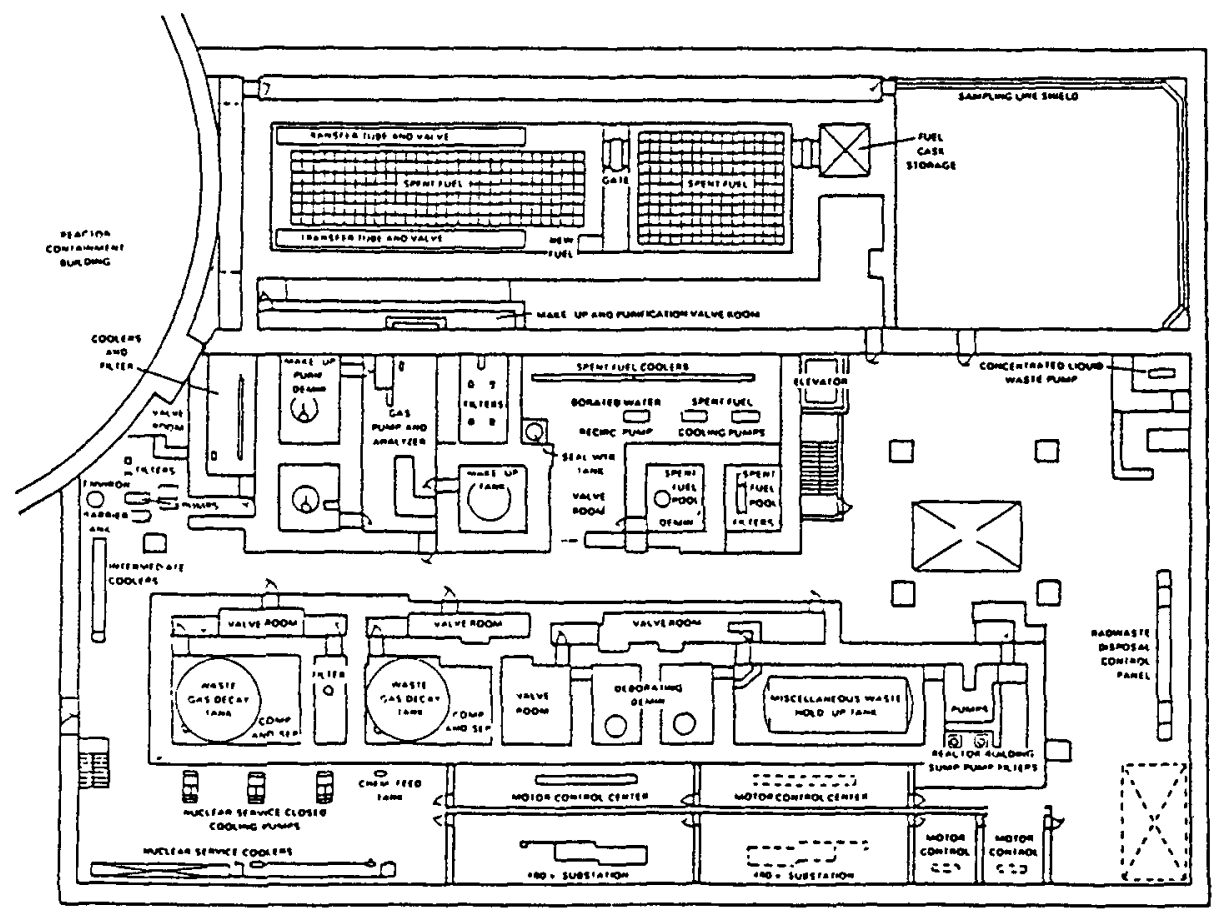

Figure 2. Auxiliary \& Fuel-Handling Bullding. 
Under the ENFDP Program, data is assembled in a form that permits input into a computerized decommissioning data system (DDS). A proprietary computer software package, MAPPER, provides a method for accumulation and manipulation of decommissioning performance information. MAPPER stands for MAintain, Prepare, and Produce Executive Reports.

Because of the volume and variety of information being collected at TMI-2, nine categories of ENFDP reports have been established and are as follows:

Volume 1 - Reactor Coolant System and Systems Decontamination

Volume 2 - Reactor Building Decontamination

Volume 3 - Reactor Defueling and Disassembly

Volume 4 - Auxiliary and Fuel Handling Building Decontamination

Volume 5 - Common Support Facilities and Systems Decontamination

Volume 6 - Plant Stability and Safety Activities

Volume 7 - Liquid Waste Handling

Volume 8 - Solid Waste Handling

Volume 9 - Radioactive Waste and Laundry Shipments

Periodic activity status and summary reports for these nine categories will be published as NUREG/CR-4315 Three Mile Island Unit 2 documents.

This report covers the period of April 9, 1979 through April 19, 1987, and summarizes shipments of radioactive solid waste to waste disposal sites and protective clothing (laundry) to commercial facilities for decontamination and cleaning. Information in this report includes: waste disposal site locations, dose rates, curie content, waste description, container type and number, volumes and weights. This data is presented in chronological order for each category. 


\subsection{SUMMARY OF SHIPMENTS}

The following tables and figures summarize the radioactive solid waste and protective clothing (laundry) shipments during the period covered by this status report. All waste shipments are classified as low-level waste, low specific activity (LSA) material.

Table 1 is a summary table of waste shipments by container type for radioactive solid waste and protective clothing (laundry) during the period of April 9, 1979, through April 19, 1987.

Note the large amounts of laundry resulting from TMI-2 cleanup (56\% of the total volume and $43 \%$ of the total weight). However, of the total 737,000 curies shipped, only six (6) curies were present in the laundry.

TABLE 1

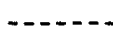

R A D I O A C T I VE SOLI D W A S T E

\begin{tabular}{|c|c|c|c|c|}
\hline CONTAINER TYPE & $\begin{array}{l}\text { NUMBER OF } \\
\text { CONTAINERS }\end{array}$ & $\begin{array}{l}\text { ACTIVITY } \\
\text { (CURIES) }\end{array}$ & $\begin{array}{l}\text { VOLUME } \\
\text { (CU.FT.) }\end{array}$ & $\begin{array}{l}\text { WEIGHT } \\
\text { (LBS.) }\end{array}$ \\
\hline 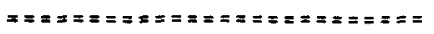 & 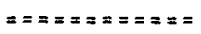 & $==$ = = = = = = = = = = & 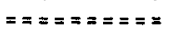 & 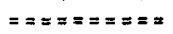 \\
\hline DRUMS & 6,054 & 106.03477 & $45,971.10$ & $1,454,142$ \\
\hline BOXES & 680 & 37.60316 & $72,203.90$ & $1,373,918$ \\
\hline LINERS & 145 & $17,729.94328$ & $21,861,40$ & 945,914 \\
\hline CASKS & 139 & $719,060.70700$ & $20,464.60$ & 708,187 \\
\hline TANKS & 4 & 1.52000 & $8,182.00$ & 48,200 \\
\hline UNIDENTIFIED CONTAINERS & * & 32.72550 & * & \\
\hline
\end{tabular}

* SOlid waste - MaY be partiaI UNIT I shipMENT.

PROTECTIVE CIOTHING (LAUNDRY)

\begin{tabular}{|c|c|c|c|c|}
\hline CONTAINER TYPE & $\begin{array}{l}\text { NUMBER OF } \\
\text { CONTAINERS }\end{array}$ & $\begin{array}{l}\text { ACTIVITY } \\
\text { (CURIES) }\end{array}$ & $\begin{array}{l}\text { VOLUME } \\
\text { (CU.FT.) }\end{array}$ & $\begin{array}{l}\text { WEIGHT } \\
\text { (LBS.) }\end{array}$ \\
\hline & $==$ = = = = = = = & 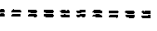 & 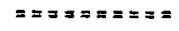 & \\
\hline RU & 26,119 & 6.25720 & $199,542.00$ & $3,426,656$ \\
\hline 0 & 516 & & $19,296.00$ & \\
\hline
\end{tabular}

* CURIES AND WEIGHTS ARE INCLUDED IN VAIUES SHOWN FOR DRUMS.

$$
\text { TOTAIS H P MENTS }
$$

\begin{tabular}{|c|c|c|c|c|}
\hline TYPE OF WASTE & $\begin{array}{l}\text { NUMBER OF } \\
\text { CONTAINERS }\end{array}$ & $\begin{array}{l}\text { ACTIVITY } \\
\text { (CURIES) }\end{array}$ & $\begin{array}{l}\text { VOLUME } \\
\text { (CU.FT.) }\end{array}$ & $\begin{array}{l}\text { WEIGHT } \\
\text { (LBS.) }\end{array}$ \\
\hline 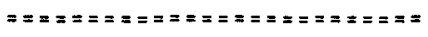 & $==$ = = = = = = = = & 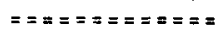 & $z==\overline{=}==\mathbf{=}=$ & $==s=z=x=s$ \\
\hline ADTOACTIVE SOLID WASTE & 7,022 & $736,968,53371$ & $168,683.00$ & $4,530,361$ \\
\hline ROTECTIVE CLOTH'NG & 26,635 & 6.25720 & $218,838.00$ & $3,426,656$ \\
\hline TOTALS & 33,657 & $736,974,79091$ & $387,521.00$ & $7,957,017$ \\
\hline
\end{tabular}


Table 2 is a summary table of waste shipments by calendar year. Note that the calendar year 1987 includes only data through April 19, 1987. The large increase in activity (curies) shipped in 1982 and 1983 resulted from disposal of Submerged Demineralizer System (SDS) liners and EPICOR prefilters used in filtering accident water.

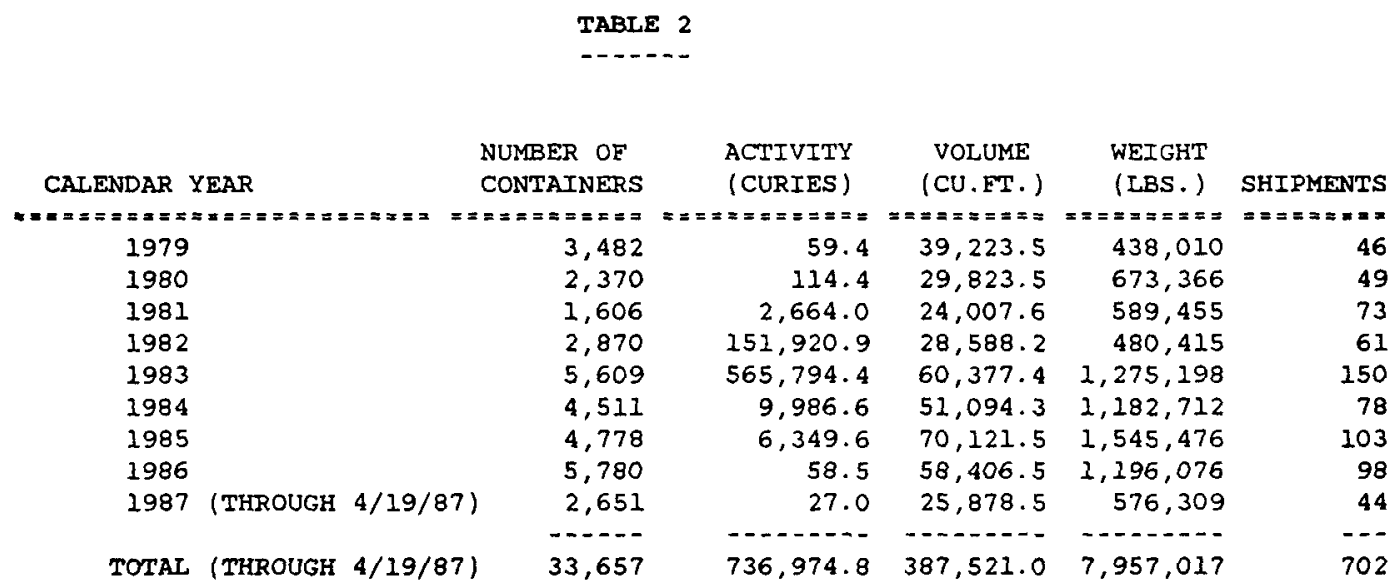

Table 3 provides a summary of waste shipments by disposal site. Additional disposal site information is 1 isted in the computer reports for TMI-2 Protective Clothing Notes and Radioactive Waste Notes (Sections 3.2 and 3.4 ). Protective clothing (Laundry) shipments are sent to commercial laundries, TIL or INTST, which are not actual disposal sites. Likewise, the QUADREX disposal site is actually a decontamination facility.

Table 3 shows that most of the high-activity waste from TMI-2 (81 percent of the total activity) was shipped to the DOE-RL Hanford disposal site. In contrast, 57 percent of the total volume was shipped to commercial laundries for decontamination; an additional 35 percent to the commercial U.S. Ecology disposal site at Richland, Washington; and the remaining 8 percent being shipped to various locations at the Idaho National Engineering Laboratory (INEL), the DOE-RL Hanford site and the Quadrex decontamination facility.

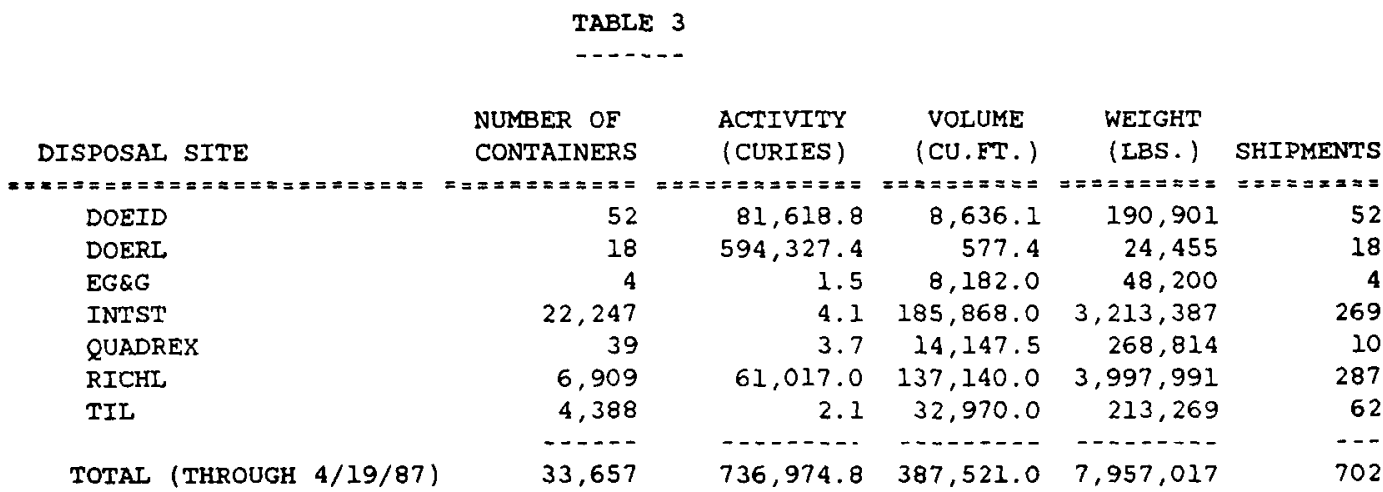


The distribution of radioactive waste and laundry shipments by calendar year and disposal site is shown in Figures 3 and 4 . The INEL radwaste shipments include sites identified as DOE-ID and EG\&G. Note the transition of laundry shipments in 1982 from the TIL commercial laundry to INTST.

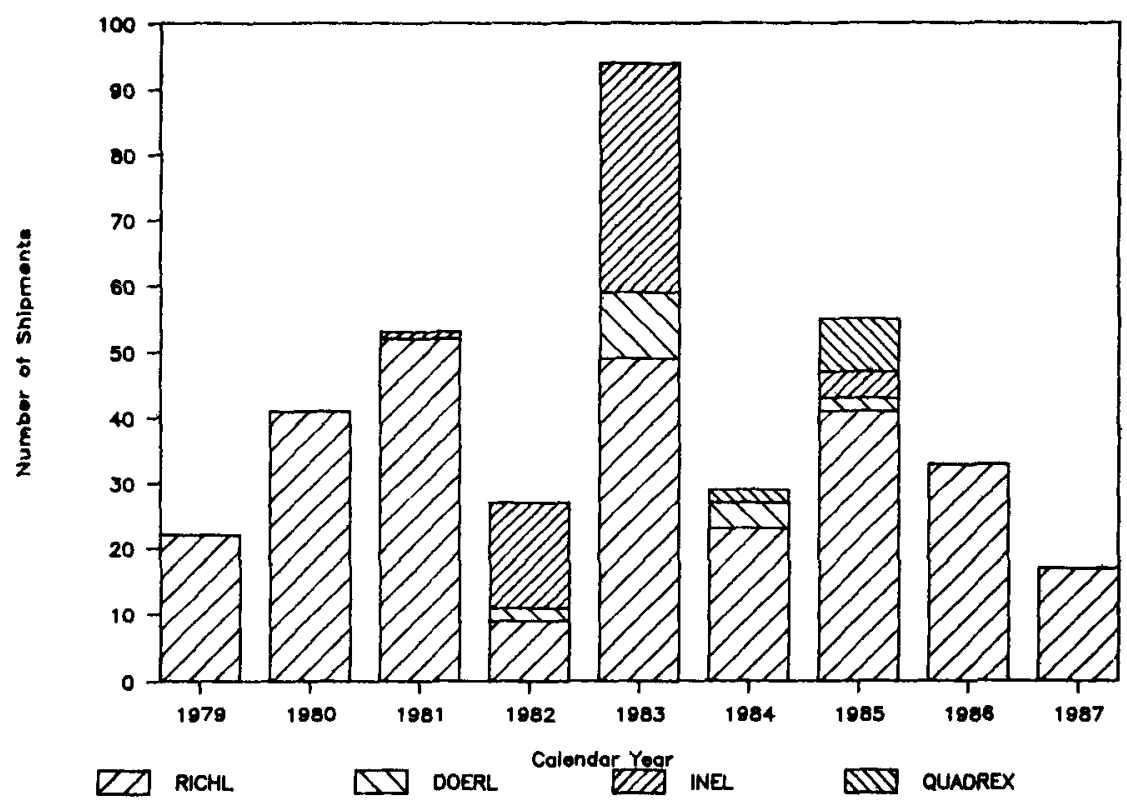

Figure 3. TMI-2 Radioactive Waste Shipments by Site

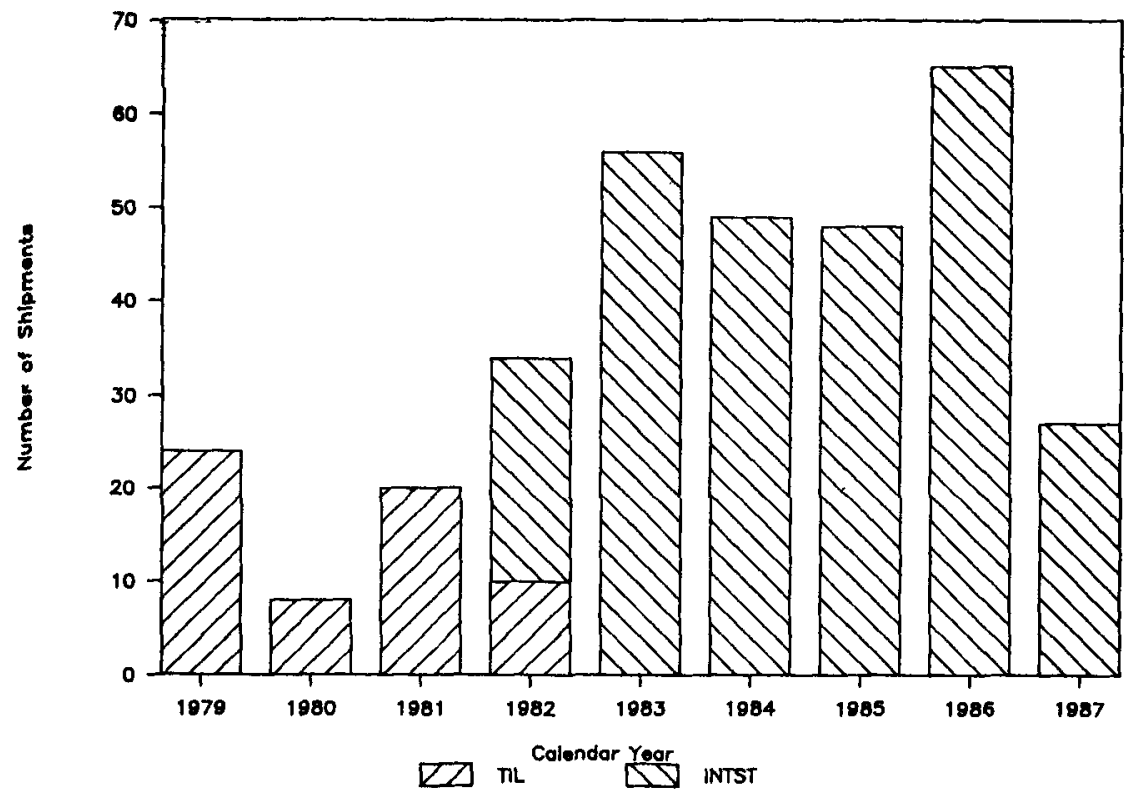

Figure 4. TMI-2 Protective Clothing (Laundry) Shipments by Site 
Figure 5 shows the breakdown of TMI-2 waste shipments between protective clothing (laundry) and solid radioactive waste. Note the significant amount of laundry shipments in comparison to radioactive waste shipments. Some of the more important waste shipment attributes are shown in Figure 6 .

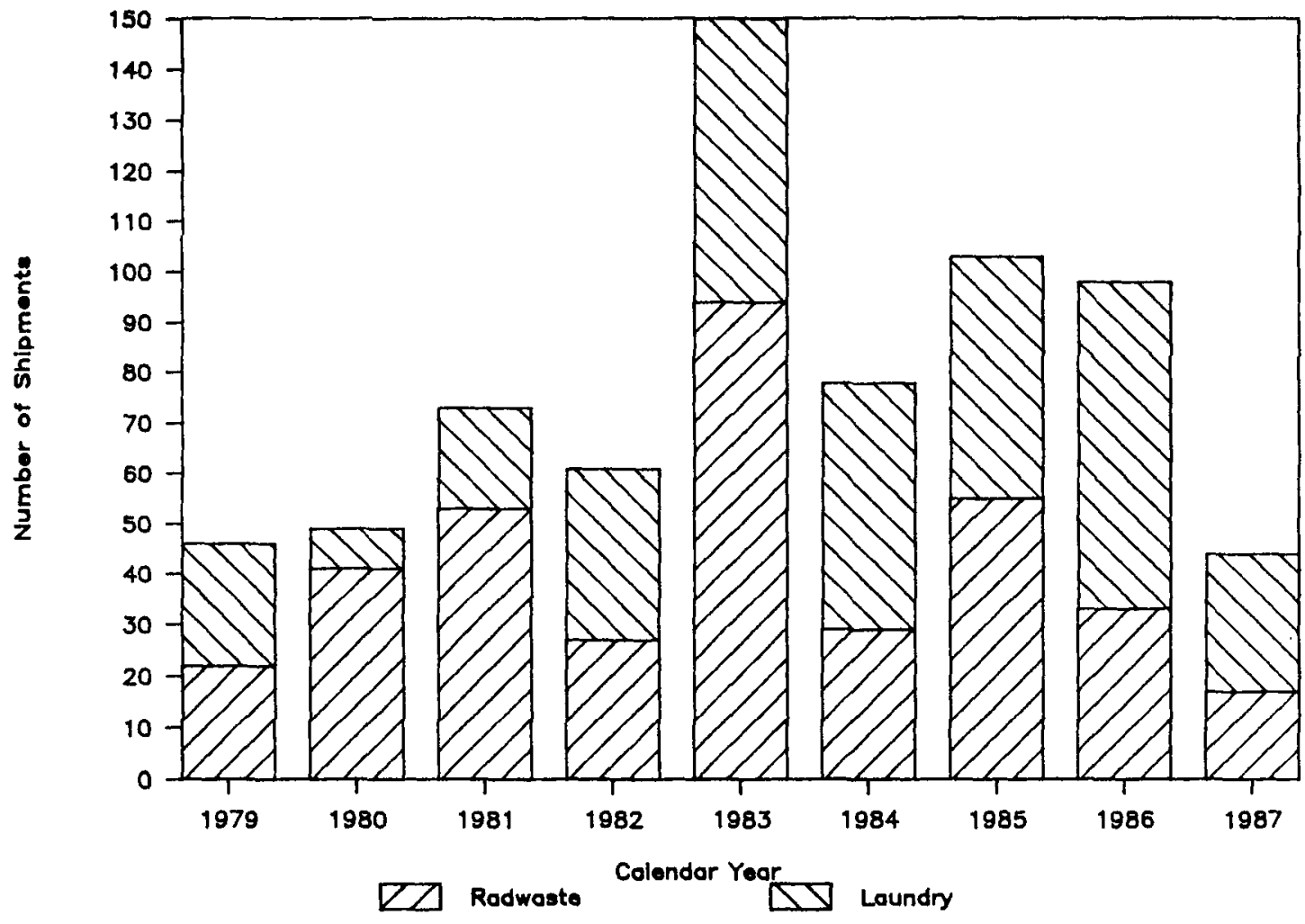

Figure 5. TMI-2 Waste Shipments 
Figure 6 depicts the comparison of TMI-2 waste shipment attributes. Note the significant spike for the activity (curies) curve, which identifies the shipment of SDS liners and EPICOR pre-filters used in processing the highly-radioactive accident water.

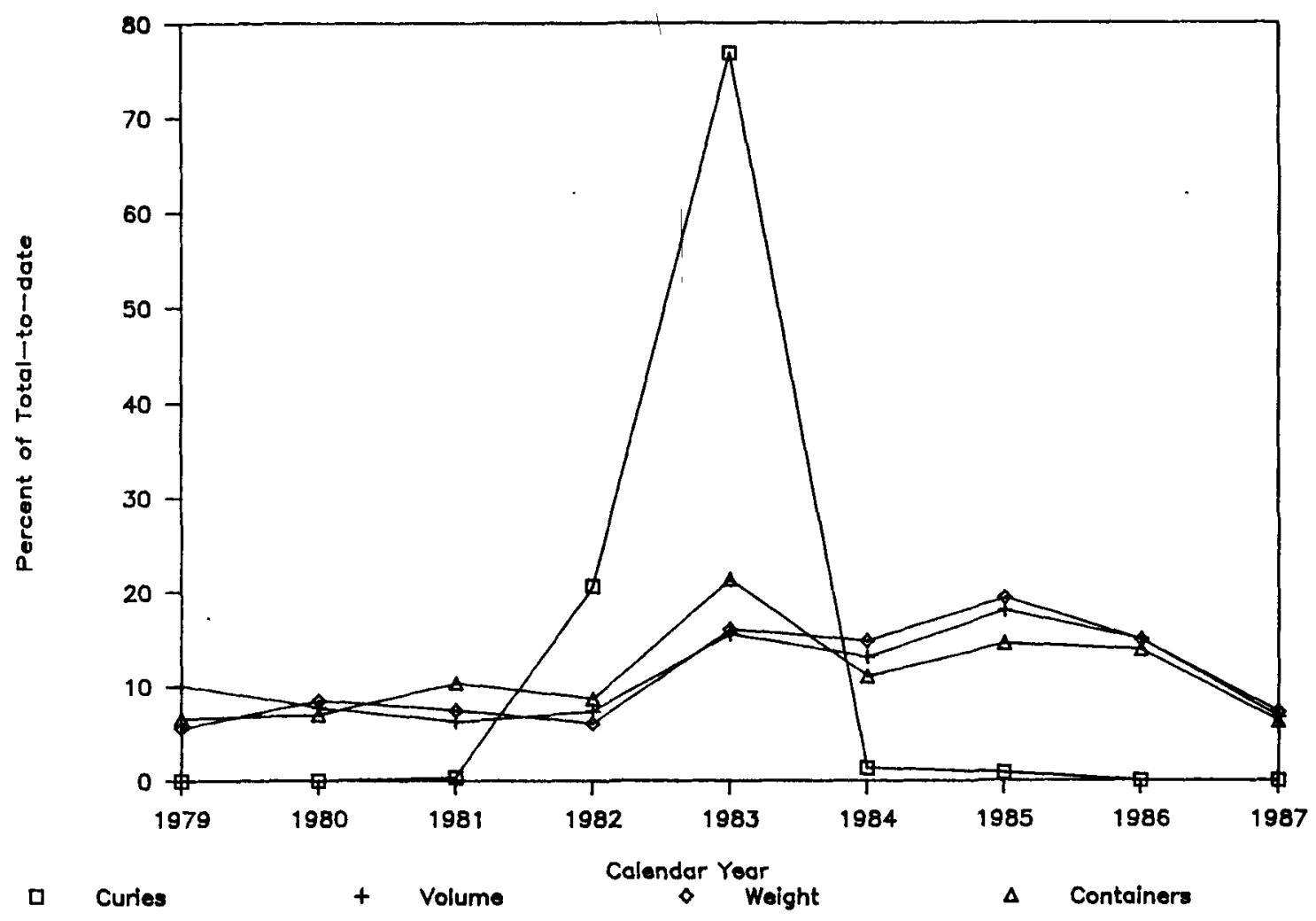

Figure 6. TMI-2 Waste Shipment Attributes 


\subsection{DESCRIPTION OF COMPUTER REPORTS}

The computer reports included in this document are:

\subsection{IMI-2 Acronyms and Abbreviations}

This report is a general listing of acronyms and abbreviations used in TMI-2 reports. All acronyms and abbreviations listed in this report are not necessarily used in this document but may be used in other volumes of NUREG/CR-4315.

\subsection{IMI-2 Protective Clothing Notes}

This report describes the notes applicable to the Protective Clothing Waste Shipment Report.

\subsection{Waste Shipment Report - Protective Clothing}

This report summarizes the protective clothing (1aundry) shipments for the period April 9, 1979, through April 19, 1987. Data columns included are: waste disposal site location, dose rates, curie content, waste description, number and type of containers, volume in cubic feet, and weight in pounds of each shipment. This report is presented in chronological order.

\subsection{IMI-2 Radioactive Waste Notes}

This report describes the notes applicable to the TMI-2 waste shipment report for Radioactive (solid) Waste. It includes a listing of the radionuclides assumed to be present in all wastes as a result of the accident.

\subsection{Waste Shipment Report - Radioactive Waste}

This report summarizes the radioactive solid waste shipments for the period Apri1 9, 1979, through April 19, 1987. Data columns included are: waste disposal site location, dose rate, curies, waste description, number and type of containers, volume in cubic feet, and weight in pounds of each shipment. This report is presented in chronological order. 


\subsection{COMPUTER REPORTS}

\subsection{TMI-2 Acronyms and Abbreviations}

PNO

MII -2

1

RID 113

$\star$

aCRONYM

UNC: DDS - ACRONYMS AND ABEREVIATIONS FOR THII-2 REPORTS M 286 I

*THIS REPORT IS A WORKING DOCUMENT AND WIIL BE UPDATED PERIODICALIY.

* (SOME ABBREVIATIONS FOUND IN DATA HAVE NOT BEEN IDENTIFIED TO DATE. THESE

*ABBREVIATIONS OR ACRONYMS WIII BE IDENTIFIED AND INCLUDED IN SUBSEQUENT

*REPORTS)

ACC

ACCESS

Acous

$\mathrm{ACQ}$

ACQUI

ADPTR

AFHB

AH

AHE

AHVG

AH $-\mathrm{C}$

ALC

ANAL,

ANN

APSR

ARTK

AUX

BIDG

$\mathrm{BLK}$

BTL (S)

BWST

B\&W

CAT

$\mathrm{CCB}$

$\mathrm{CCT}$

CCTB

$\mathrm{CCTV}$

CDT

CET

CHEM ADD

CIIR

CLR (S)

CNTR (LD)

CNIRL

COL

COMP

COMPOSIT

CONC

COND

CONN

CONST

CONT

CONTR

CORR

ACOUSTIC OR ACOUSTICAT

ACQUISITION

ACOUISITION

ADAPTER

AUXIIIARY AND FUEI HANDLING BUIIDING

ATR GANDLING

AIR HANDLING EQUIPMENT

AIR HANDIING VAIVE ' $G$ '

AIR HANDLING VAIVE ' $C$ '

AUXILIARY IIQUID CLEANUP (EPICOR 2)

ANAIYSIS OR ANAIYZE

ANNULUS

AXIAL POWER SHAPING ROD

AIRIOCK

AUXILIARY (BUIIDING)

BUIIDING

BLOCK

BOTILE ( $S$ )

BORATED WATER STORAGE TANK

BABCOCK \& WILCOX

CHEMICAL ADDITION TANK

CHEMICAL CLEANING BUIIDING

CHEICAL CLEANING TANK

CHEMICAL CLEANING TANK ' $B$ '

CLOSED CIRCUIT TELEVISION

CONDENSATE DRAIN TANK

CORE FLOOD TANK

CHEMICAL ADDITION

CHECK

COOLER ( $S$ )

CONIROL OR CONIROLIED

CONTROL

COLUMAN

COMPACTOR

COMPOSITE

CONCENTRATED

CONDENSER OR CONDENSATE

CONNECT OR CONNECTOR

CONSTRUCT OR CONSTRUCTION

CONTAMINATED

CONTRACTOR

CORRIDOR 


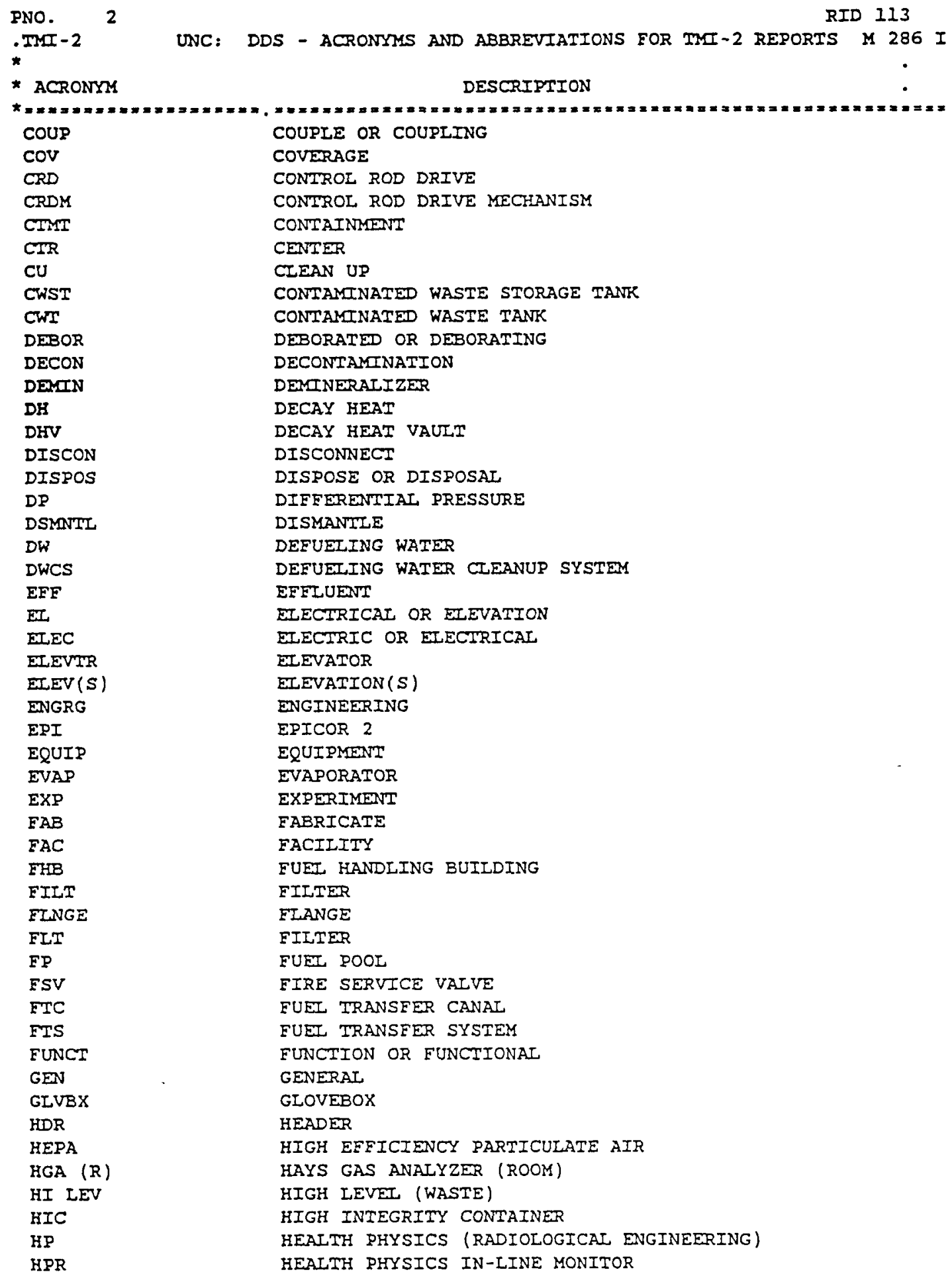




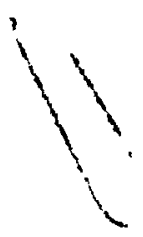

PNO

RID 113

TMI - 2

UNC: DDS - ACRONYMS AND ABBREVIATIONS FOR TMI-2 REPORTS M 286 I

$*$

* ACRONYM

DESCRIPIION

\section{HRF-6B}

HSE

HSERPG

HVAC

$\mathrm{H}-2$

ICC

IIF

INE

INJ

INSP

INST

INSTL

INTERMED

IX

LAB

ID

IL

LN (S)

LOCA

IP

LSA

LTSE

MAG

MAINT

MANO

MAIL

$M B$

$M C$

$M C$ CIR

$\mathrm{MDH}$

MDHR

MEAS

MGIT

MISC

MOD

MONIT (S)

MOV

MSA

MT

MU

MUE

MUP

MUV

$M U \& P$

MW

MWHT

MWT

NEUT

NI

NLB

HIGH RAD FIITER GLOVEBOX

HOUSE

HOUSEKEEPING

HEAT, VENTILATION, AIR CONDITIONING

FYDROGEN

INTERMEDIATE CLOSED COOLING WATER SYSTEM

INTERNALS INDEXING FIXTURE

INELUENT

INJECTION

INSPECT OR INSPECTION

INSTRUMENT OR INSTRUMENTATION

INSTALL OR INSTALIATION

INTERMEDIATE

ION EXCHANGE

I.ABORATORY

LEAD

LOW LEVEL (WASTE)

IINE(S)

LOSS OF COOLANT ACCIDENT

LOW PRESSURE

LOW SPECIEIC ACTIVITY (WASTE)

LONG TERM STORAGE FACILITY

MAGNETIC

MAINTAIN OR MAINTENANCE

MANOMEIER

MATERIAI

(CURRENTIY UNRNOWN)

MOTOR CONTROI

MOTOR CONTROL CENTER

MINI-DECAY HEAT

MINI DECAY HEAT REMOVAL SYSTEM

MEASURE OR MEASUREMENT

MANAGEMENT

MISCELIANEOUS

MODIFICATION OR MODEL (ROOM)

MONITOR (S)

MOTOR OPERATED VALVE

MINE SAFEIY APPIIANCE

EYPTY

MAKE UP

MAKE UP FILTER

MAKE UP PUMP

MAKE UP VALVE

MAKE UP AND PURIEICATION

MISCELLANEOUS WASTE

MISCELIANEOUS WASTE HOLDUP TANK

MISCELIANEOUS WASTE TANK

NEUTRON

NUCLEAR INSTRUMENT OR INSTRUMENTATION

MANUEACTURER'S NAME FOR HYDROLASER PUMP 


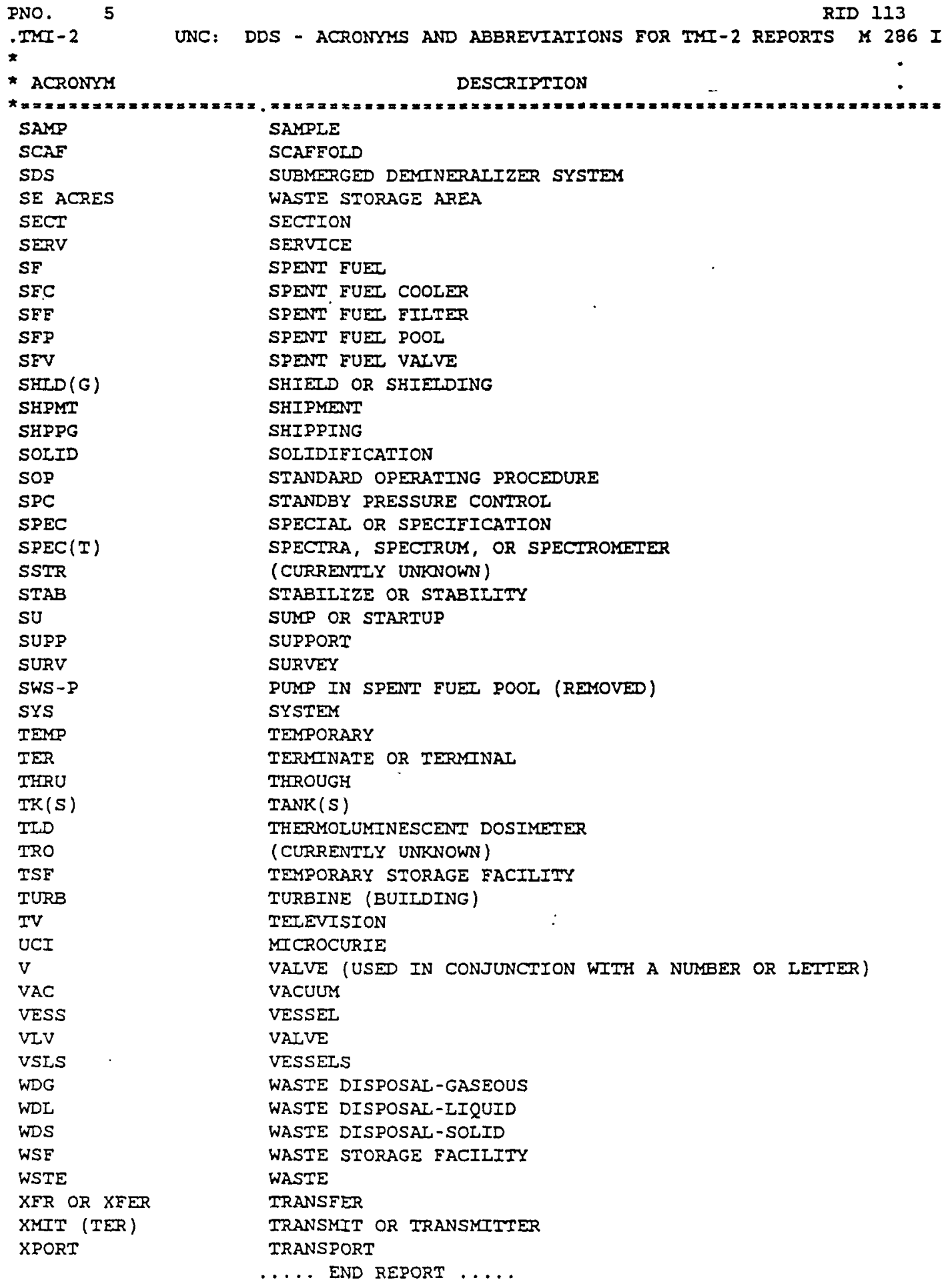




\subsection{COMPUTER REPORTS}

4.2 IMI-2 Protective Clothing Notes 
PAGE NO. 1 .TMI-2 UNC: DDS - WASTE SHIPMENT REPORT - LAAUNDRY NOTES

THIS REPORT IS A WORKING DOCUMENT AND WILL BE UPDATED PERIODICALLY. NOTES:

$--\cdots--$

1. DISPOSAL SITE COLUMN ENTRIES ARE: (COMMERCIAL LAUNDRIES)

TIL - TRISTATE INDUSTRIAL LAUNDRY

INTST - INTERSTATE UNIFORM COMPANY, NOW INTERSTATE NUCLEAR SERVICES

2. RADIONUCLIDES MEASURED ON PROTECTIVE CLOTHING USED DURING CLEANUP OPERATIONS AT TMI-2 ARE SHOWN BELOW AS AVERAGE WEIGHT PERCENTAGES:

\begin{tabular}{rrlll} 
NUCLIDE & \multicolumn{3}{l}{ NUCLIDE } & \multicolumn{2}{l}{ NUCLIDE } \\
\hline MN $54-$ & $0.05 \%$ & Y $90-4.11 \%$ & TE $135 \mathrm{M}-1.20 \%$ \\
CO $57-$ & $0.10 \%$ & RU $106-1.00 \%$ & CS $134-1.34 \%$ \\
CO $60-$ & $57.20 \%$ & RH $106-1.00 \%$ & CS $137-13.50 \%$ \\
SR $90-$ & $4.11 \%$ & SB $125-1.39 \%$ & BA $137 M-13.80 \%$
\end{tabular}

3. LAUNDRY CONTAINERS (CNTRS) ARE 55-GAILON DRUMS AND 42-CUBIC FOOT BOXES. BOXES ARE IDENTIFIED BY THE LETTER B (E.G. 4B). DRUMS ARE IDENTIFIED BY THE LETTER D (E.G. 3D).

4. TYP - A = ACTIVATION, $C=$ CONTAMINATION

5. DNA = DATA NOT AVAILABLE; NEG = NEGLIGIBLE

6. DOT S/CLS - NOT APPLICABLE (N/A)

7. FOR I.AUNDRY SHIPMENTS, WEIGHTS WERE GENERALLY ESTIMATED AND ARE NOT RELEVANT. LAUNDRY CHARGES ARE BASED ON INDIVIDUAL ITEMS SUCH AS COVERALLS, SHOE COVERS, GLOVES, ETC.

8. BLANK SPACES IN ALI COLUMNS INDICATE THAT VALUES ARE INCLUDED IN THE PREVIOUS LINE. 


\subsection{COMPUTER REPORTS.}

4.3 TMI-2 Waste Shipment Report - Protective Clothing 
DATE 093087 PAGE

PNO 1 TMI-2 1 UNC DDS - WASTE SHIPMENT REPORT - PROTECTIVE CLOTHING ${ }^{\text {RID }} 36286 \mathrm{C}$

*
$*$ DATE NUPMT SYS/COMP DISPOSAL.

NOTE 1

NOTE 2

NOTE3

NOTE 6

$\begin{array}{ll}790416 & 79036 \\ 790430 & 79041 \\ 790516 & 79049 \\ 790525 & 79053 \\ 790613 & 79058 \\ 790620 & 79063 \\ 790626 & 79065 \\ 790705 & 79066 \\ 790712 & 79071 \\ 790718 & 79077 \\ 790723 & 79078 \\ 790725 & 79080 \\ 790801 & 79083 \\ 790809 & 79088 \\ 790816 & 79094 \\ 790823 & 79097 \\ 790830 & 79110 \\ 790906 & 79114 \\ 790919 & 79121 \\ 790927 & 79123 \\ 791004 & 79129 \\ 791018 & 79134 \\ 791113 & 79141 \\ 791207 & 79162 \\ 800222 & 80018 \\ 800319 & 80026 \\ 800609 & 80050 \\ 800623 & 80059 \\ 800905 & 80105 \\ 801003 & 80122 \\ 801107 & 80141 \\ 801126 & 80147 \\ 810129 & 81010 \\ 810227 & 81025 \\ 810320 & 81031 \\ 810414 & 81040 \\ 810515 & 81054 \\ 810611 & 81069 \\ 810625 & 81080 \\ 810709 & 81088 \\ 810730 & 81094 \\ 810813 & 81098 \\ 810825 & 81102 \\ 810826 & 81103 \\ 810901 & 81106 \\ 810901 & 81108 \\ 810924 & 81113 \\ & \end{array}$

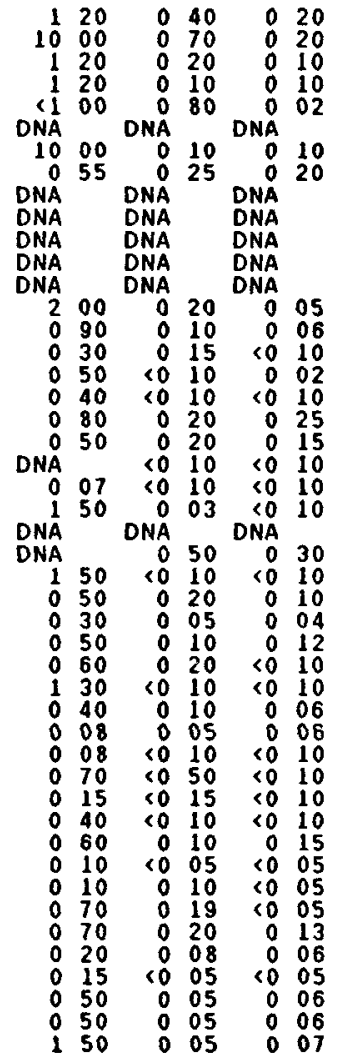

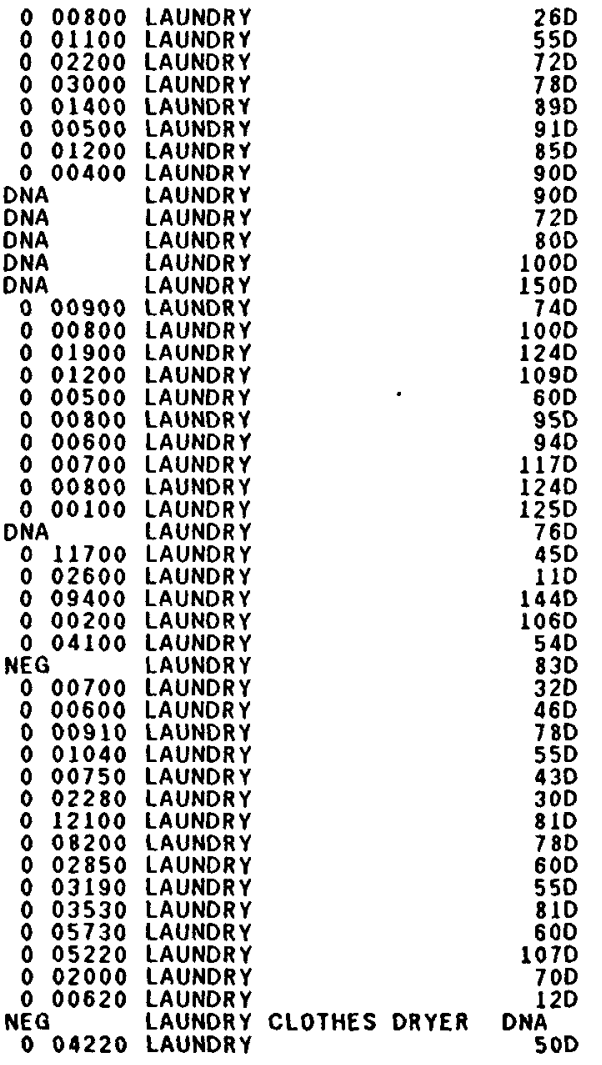

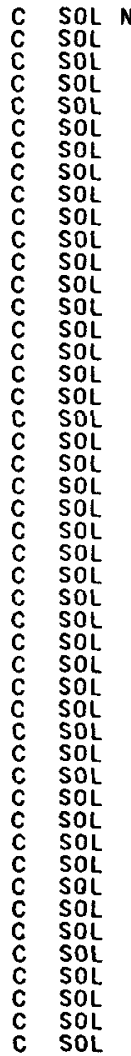

\begin{tabular}{|c|c|}
\hline 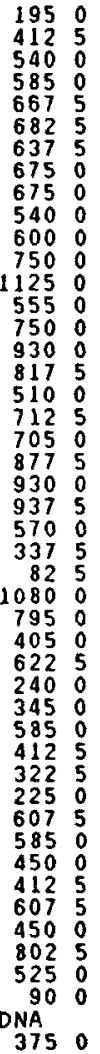 & $\begin{array}{l}\text { NA } \\
\text { NA } \\
\text { NA } \\
\text { NA } \\
\text { NA } \\
\text { NA } \\
\text { NA } \\
\text { NA } \\
\text { NA } \\
\text { NA } \\
\text { NA } \\
\text { NA } \\
\text { NA } \\
\text { NA } \\
\text { NA } \\
\text { NA } \\
\text { NA } \\
\text { NA } \\
\text { NA } \\
\text { NA } \\
\text { NA }\end{array}$ \\
\hline
\end{tabular}


DATE 093087 PAGE 3

PNO 2 UNC DDS - WASTE SHIPMENT REPORT - PROTECTIVE CLOTHING ${ }^{\text {RID }}$ M6 $286 \mathrm{C}^{36}$

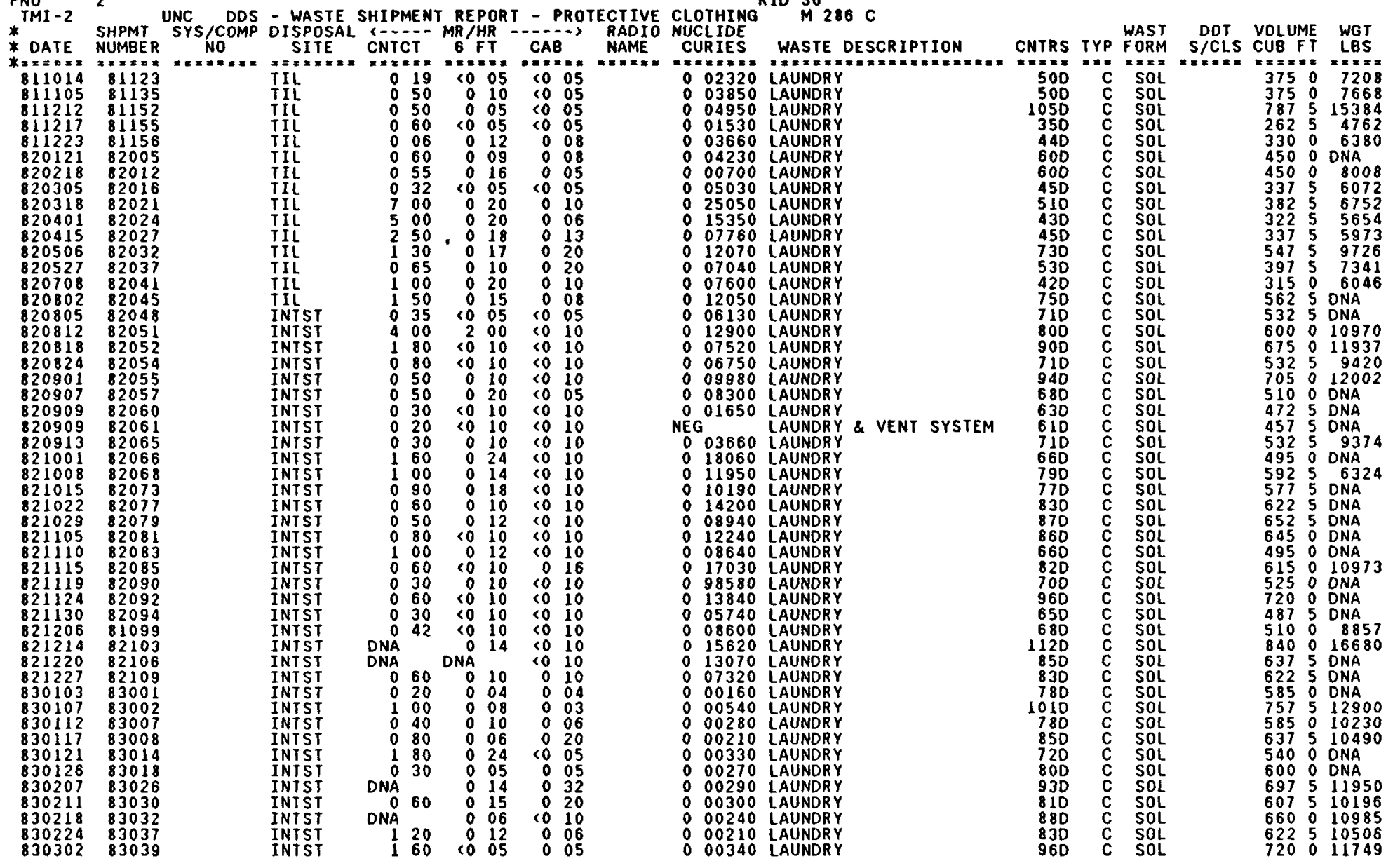




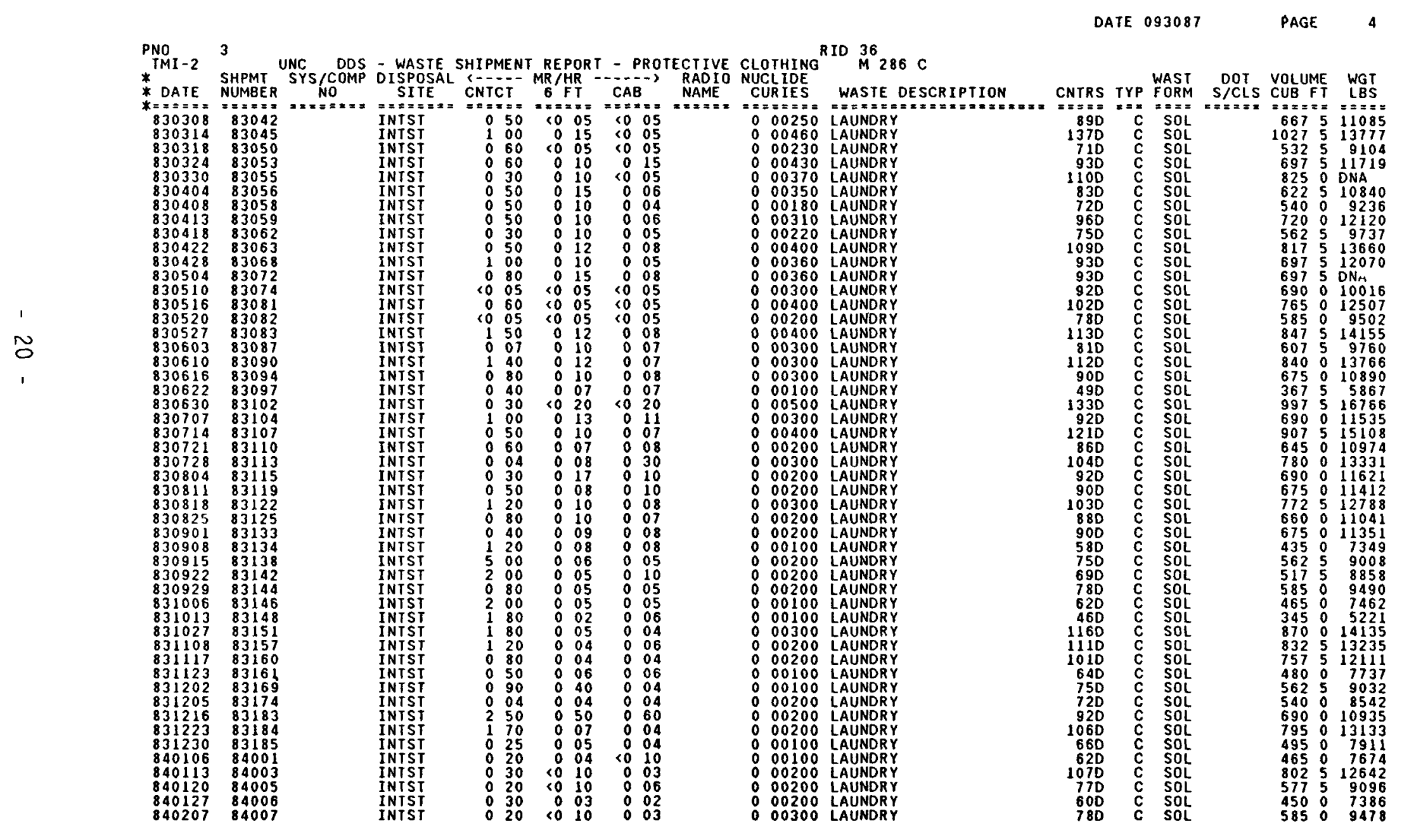


DATE 093087 PAGE

PNO 4 TMI-2 UNC DOS - WASTE SHIPMENT REPORT - PROTECTIVE CLOTHING ${ }^{\text {RID }} 36$ M $286 \mathrm{C}$

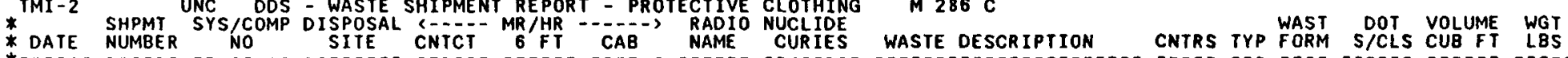

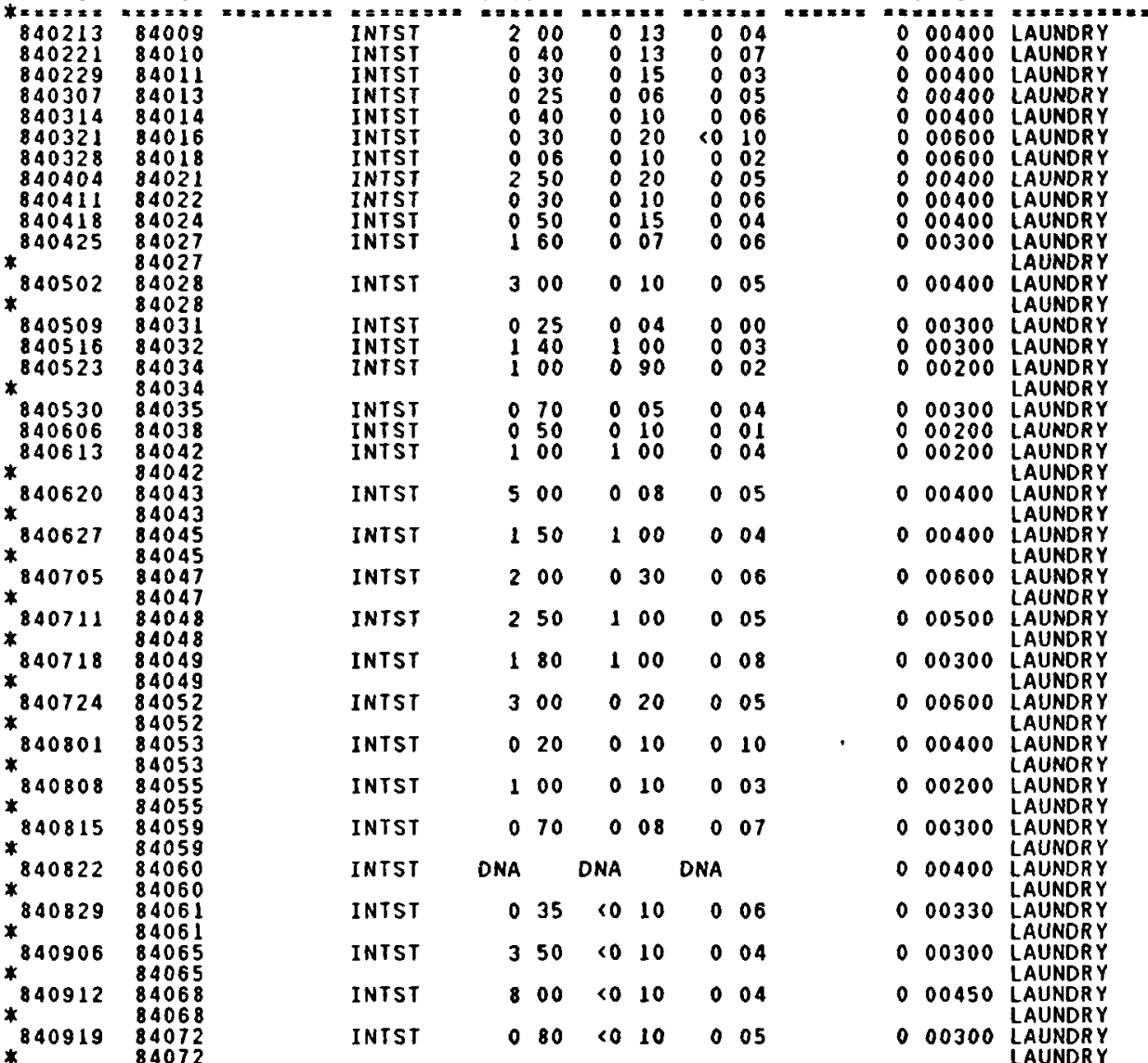

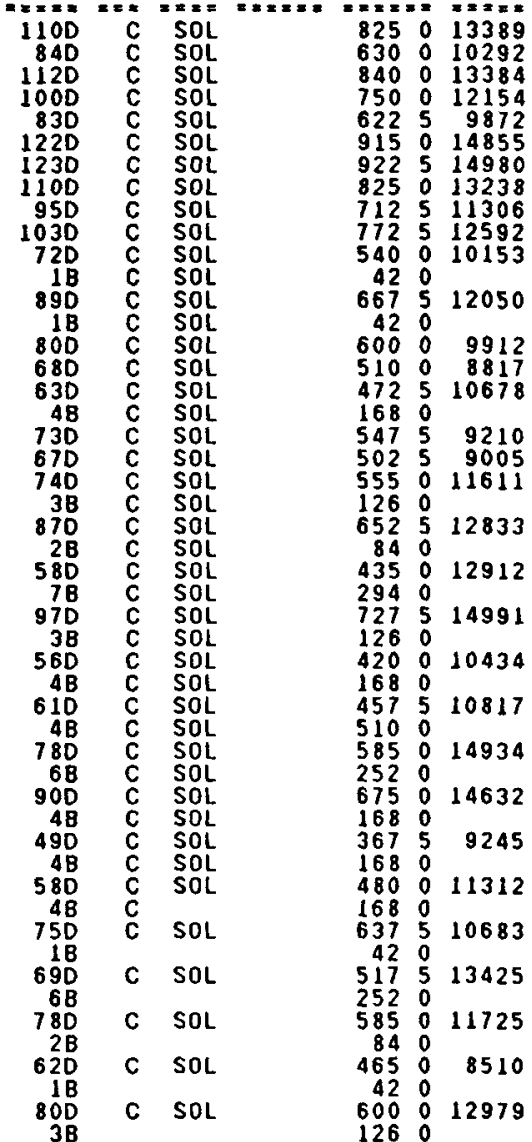




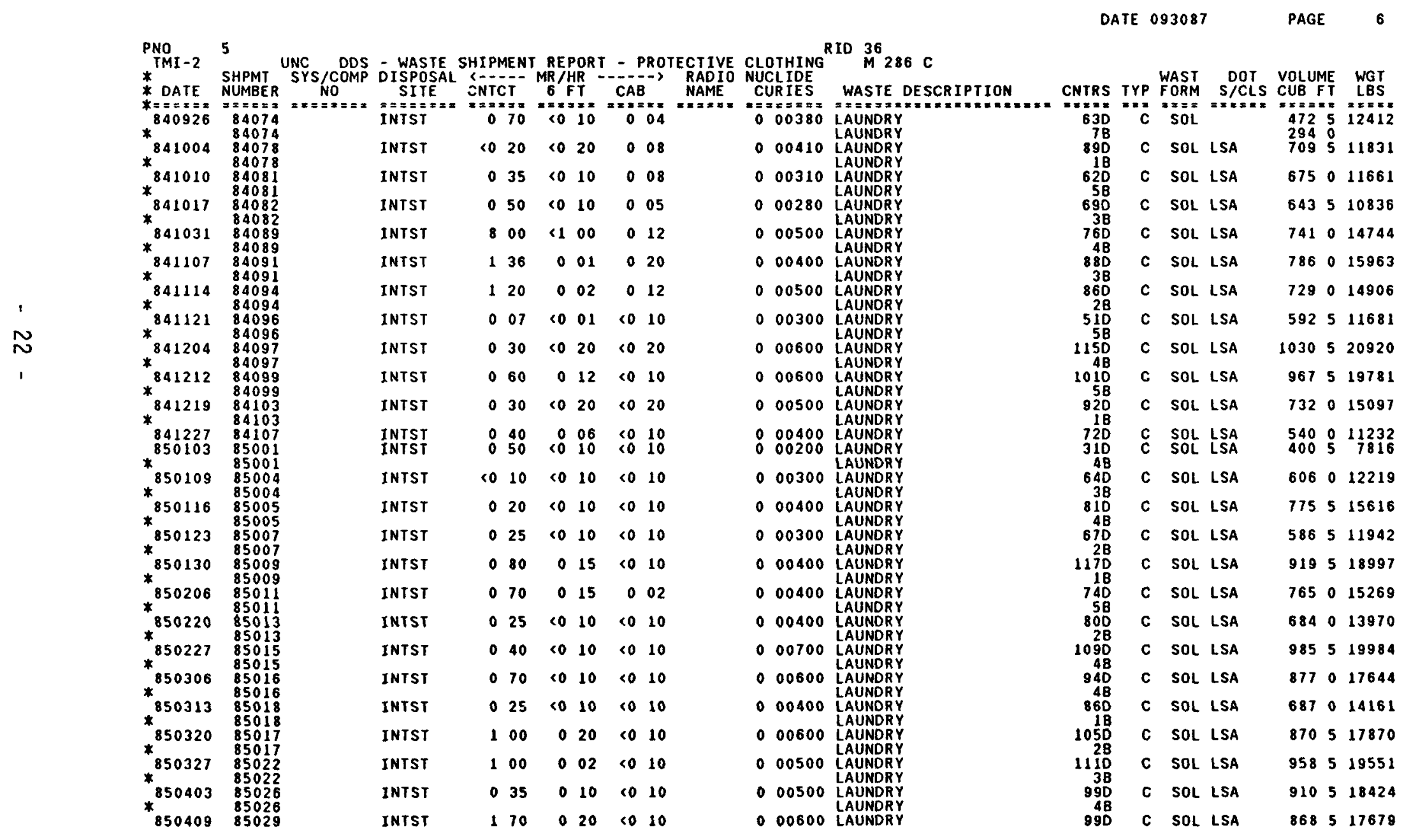




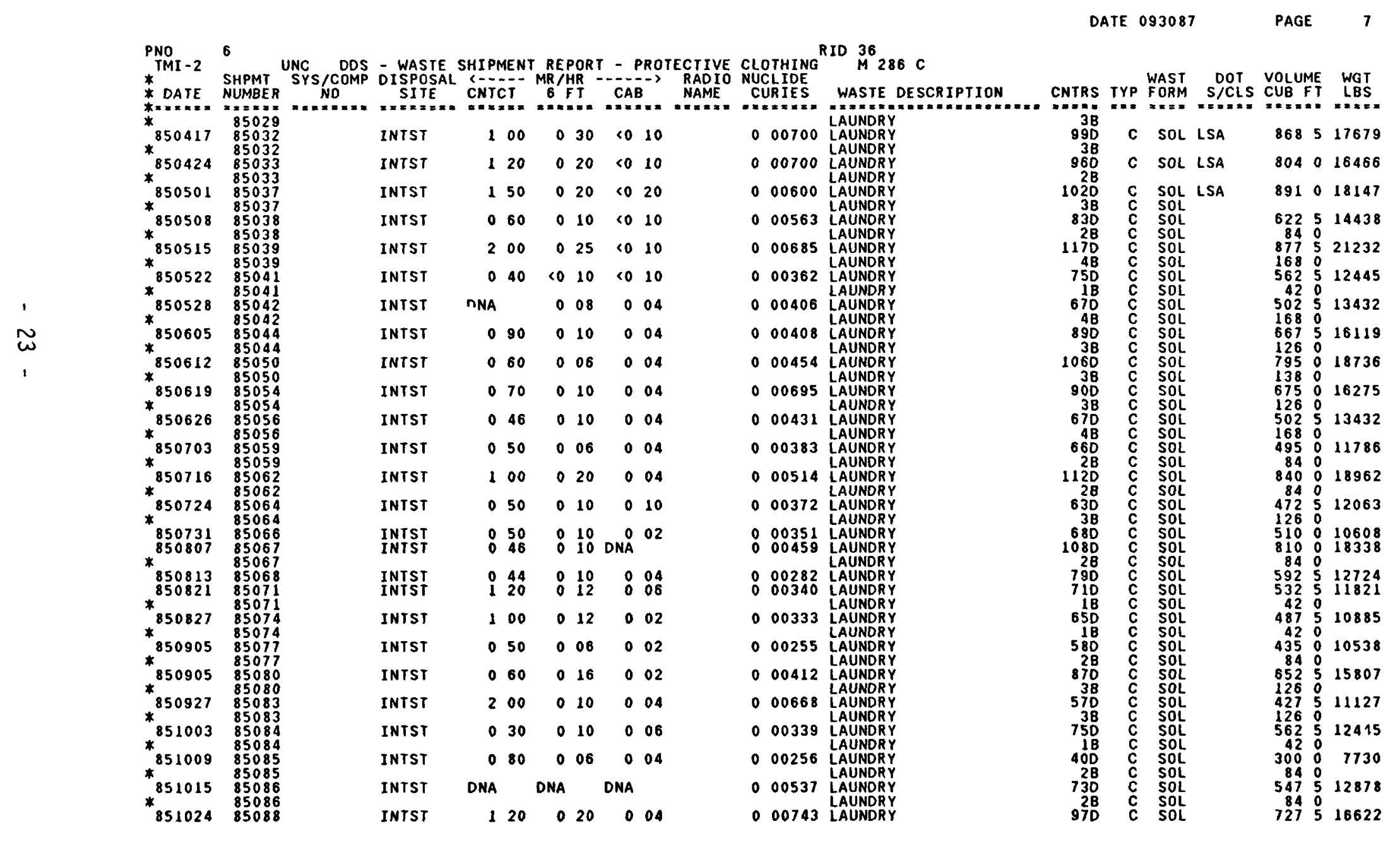


PNO 7 UMI-2 SNC DDS - WASTE SHIPMENT REPORT - PROTECTIVE CLOTHING ${ }^{\text {RID }} 36286 \mathrm{C}$

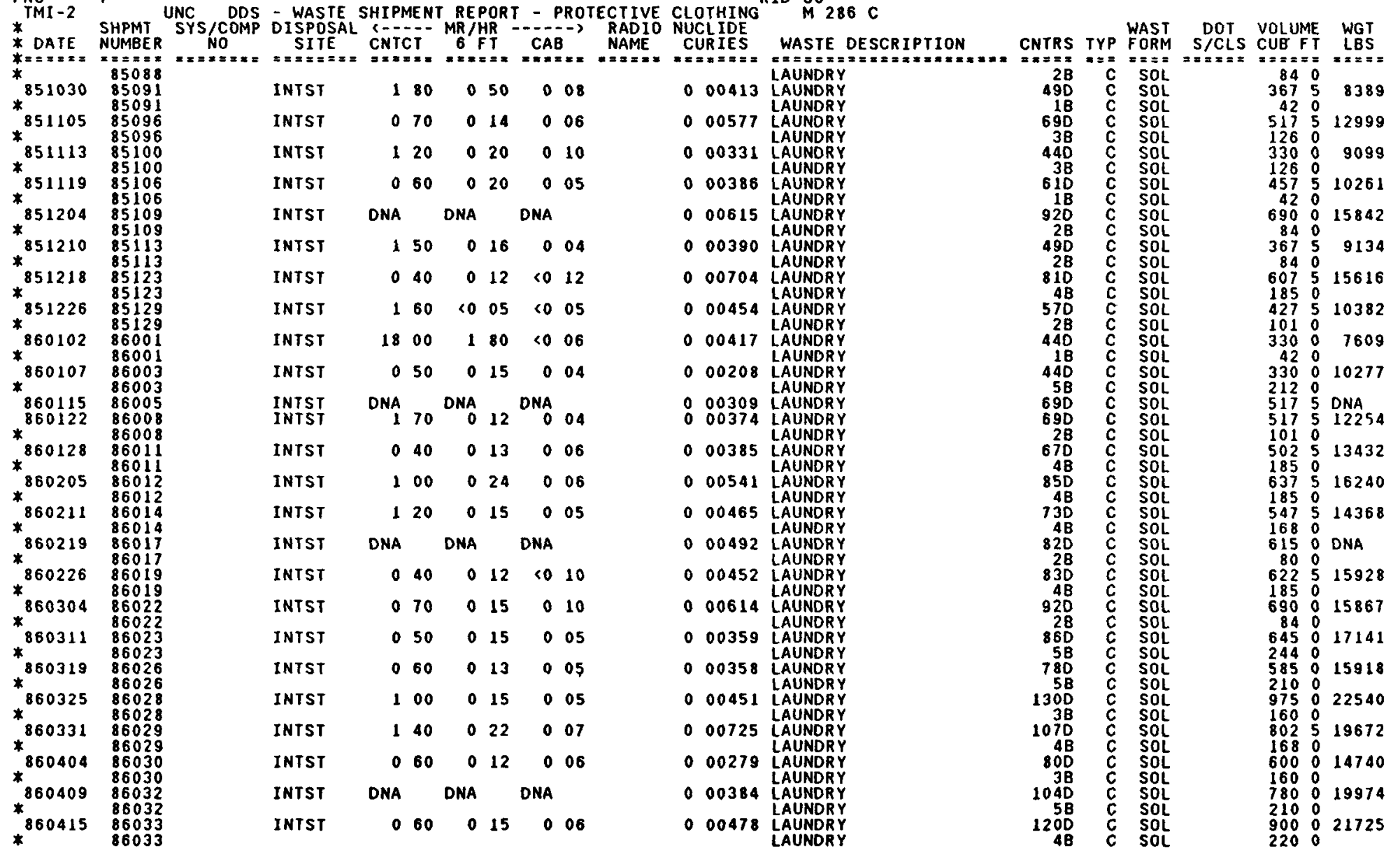


DATE 093087 PAGE

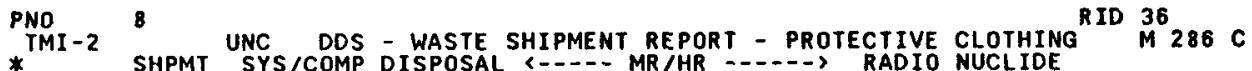

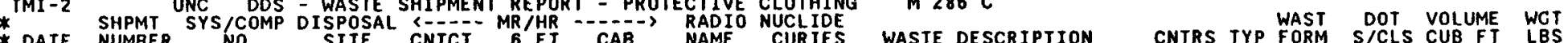

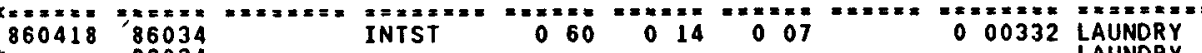

$860423 \quad 86035$

INTST $\quad 100 \quad 010 \quad 006$

TAUNDRY

86042986037

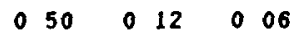

- 00379 Launory

*860507 8603

INTST 0 40 0 10 010

0 00507 LAUNDRY

860514

INTST $\quad 320 \quad 050 \quad 028$

o 00395 LAUNDRY

828043

INTST $180 \quad 020 \quad 0 \quad 08$

8605278602

$\begin{array}{lllllll}\text { INTST } & 0 & 60 & 0 & 14 & 0 & 10\end{array}$

INTST $\quad 0 \quad 30 \quad 0 \quad 10 \quad 0 \quad 06$

$860603 \quad 86050$

INTST $300 \quad 0 \quad 14 \quad 006$

INTST DNA DNA DNA

* 8001186053

$860618 \quad 86056$

$\begin{array}{llllllllllll}1 & 00 & 0 & 14 & 0 & 04\end{array}$

$\begin{array}{lllllll}\text { INTST } & 0 & 50 & 0 & 08 & 0 & 10 \\ \text { INTST } & 0 & 30 & <0 & 10 & 0 & 08\end{array}$

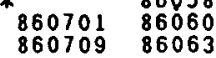

*860716 86067

$\begin{array}{llllll}3 & 50 & 2 & 60 & 0 & 08\end{array}$

86072286069

$860730 \quad 86070$
$\times$

$860805 \quad 86075$
$*$
860813
86075

$\begin{array}{lllllll}\text { INTST } & 1 & 50 & \text { DNA } & \text { DNA } & \\ \text { INTST } & 0 & 30 & 0 & 08 & 0 & 10\end{array}$

INTST

DNA DNA DNA

$\begin{array}{llllll}0 & 70 & 0 & 10 & 0 & 06\end{array}$

$860813 \quad 86077$

INTST

INTST

$160 \quad 020 \quad 008$

$\begin{array}{llllll}0 & 50 & 0 & 08 & 0 & 10\end{array}$

$860827 \quad 86083$

INTST

INTST

$\begin{array}{llllll}60 & 0 & 12 \quad 012\end{array}$

86090486087

INTST

$\begin{array}{llllll}0 & 18 & 0 & 04 & 0 & 06\end{array}$

* 8609108

* $860925 \quad 86094$

INTST

DNA DNA DNA

INTST 050 O $12 \quad 0 \quad 08$

* $861002 \quad 86098$

INTST DNA DNA DNA

$* 861009 \quad 86099$
$* \quad 86099$

INTST $\quad 0 \quad 30 \quad 0 \quad 05 \quad 0 \quad 05$

0 00535 LAUNDRY

000333 LAUNDRY

000260 LAUNDRY

000489 LAUNDRY

$0 \quad 00292$ LAUNDRY

000287 LAUUNDRY

000261 LAUNDRY

000331 LAUUNDRY

000349 LAUNDRY

DNA

AUNDRY

000381 LAUNDRY

- 00514 Laundry

000339 LAUNDRY

000218 LAUNDRY

000422 LAUNDRY

- 00320 LAUNDRY

0 00408 LAUNDRY

000363 LAUNDDRY

LAUNDRY
AUNORY

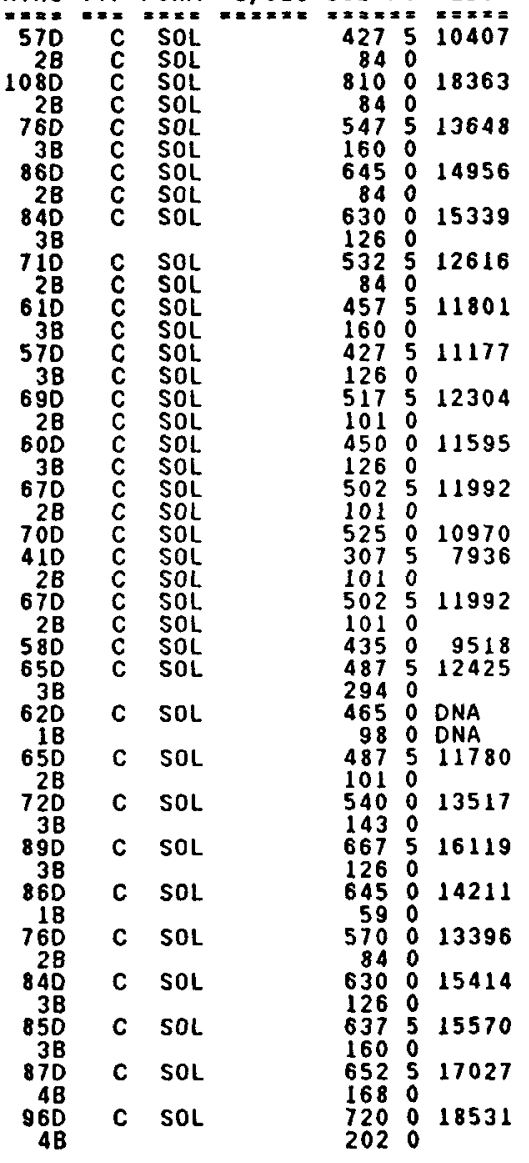




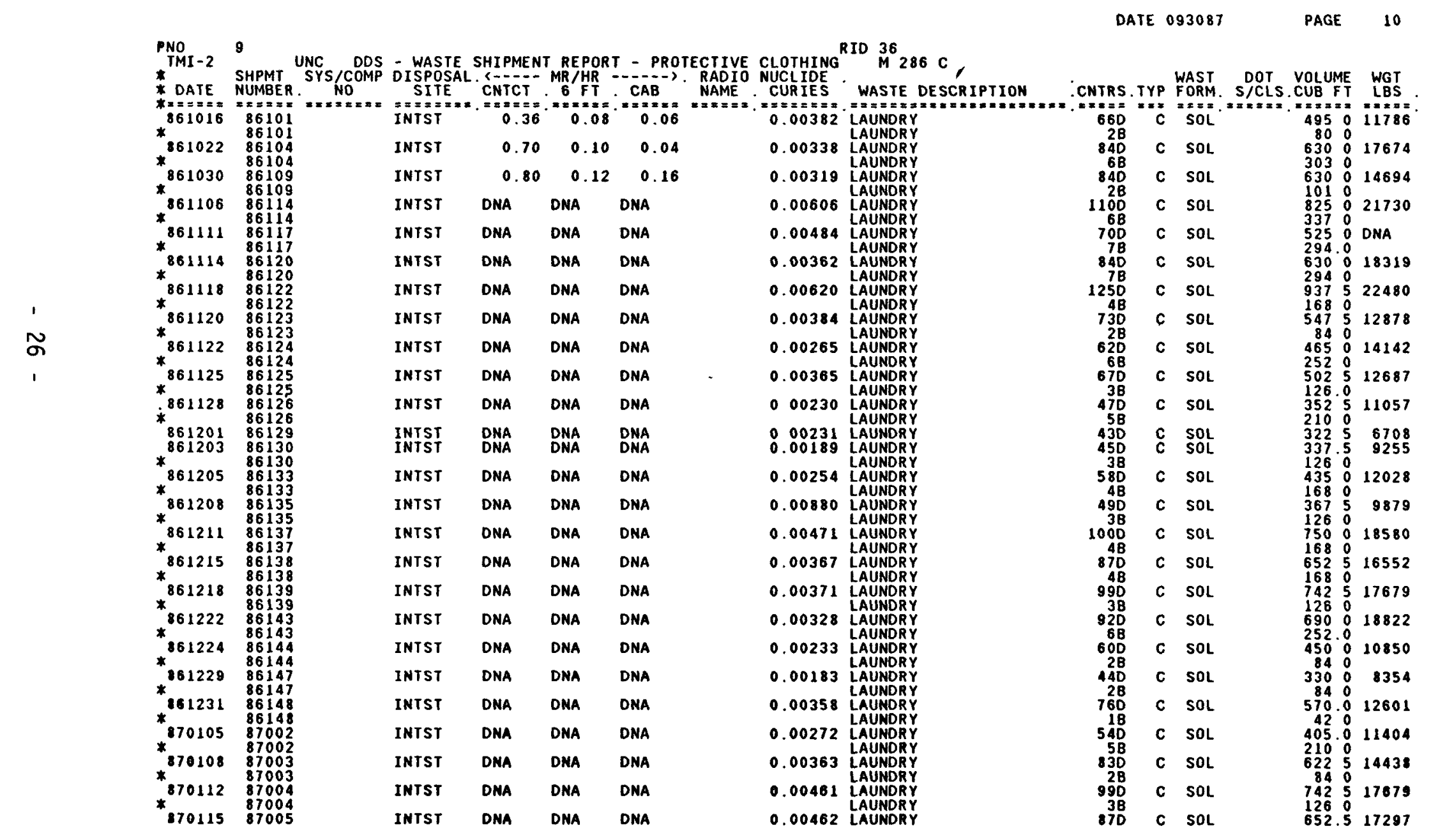


PNO 10
TMI-2
SHPMT UNC: DYS DOS - WASTE SHIPMENT REPORT - PROTECTIVE CLOTHING

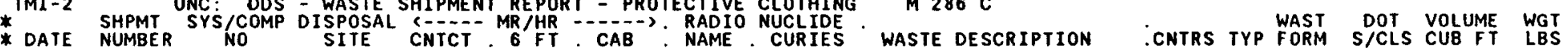

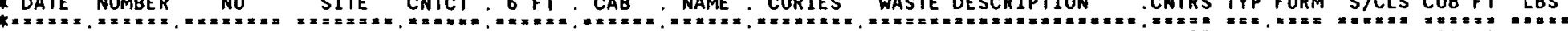

\begin{tabular}{|c|c|c|c|c|c|}
\hline 870119 & $\begin{array}{l}87007 \\
87007\end{array}$ & INTST & DNA & DNA & DNA \\
\hline 870122 & 87008 & INTST & DNA & DNA & DNA \\
\hline 870126 & $\begin{array}{l}87010 \\
87010\end{array}$ & INTST & DNA & DNA & DNA \\
\hline 870129 & 87012 & INTST & DNA & DNA & DNA \\
\hline 870202 & 87013 & INTST & DNA & DNA & DNA \\
\hline 870205 & 87014 & INTST & DNA & DNA & DNA \\
\hline 870209 & 87017 & INTST & DNA & DNA & DNA \\
\hline 870212 & 87019 & INTST & DNA & DNA & DNA \\
\hline 870216 & 87021 & INTST & DNA & DNA & DNA \\
\hline 870219 & 87022 & INTST & DNA & DNA & DNA \\
\hline 870223 & 87025 & INTST & DNA & DNA & DNA \\
\hline 870226 & 87026 & INTST & DNA & DNA & DNA \\
\hline 870302 & 87030 & INTST & DNA & DNA & DNA \\
\hline 870305 & 87033 & INTST & DNA & DNA & DNA \\
\hline 370309 & 87034 & INTST & DNA & DNA & DNA \\
\hline 870312 & 87036 & INTST & DNA & DNA & DNA \\
\hline 870316 & 87039 & INTST & DNA & DNA & DNA \\
\hline 70319 & 87044 & INTST & DNA & DNA & DNA \\
\hline 70323 & 87045 & INTST & DNA & DNA & DNA \\
\hline $\begin{array}{l}870326 \\
870402\end{array}$ & $\begin{array}{l}87048 \\
87050\end{array}$ & $\begin{array}{l}\text { INTST } \\
\text { INTST }\end{array}$ & $\begin{array}{l}\text { DNA } \\
\text { DNA }\end{array}$ & $\begin{array}{l}\text { DNA } \\
\text { DNA }\end{array}$ & $\begin{array}{l}\text { DNA } \\
\text { DNA }\end{array}$ \\
\hline 10416 & 87055 & INTST & DNA & ONA & DNA \\
\hline 70419 & 87051 & INTST & DNA & DNA & DNA \\
\hline
\end{tabular}

PROTECTIVE CLOTHING (LAUNORY)

GRANO-TOTAL -

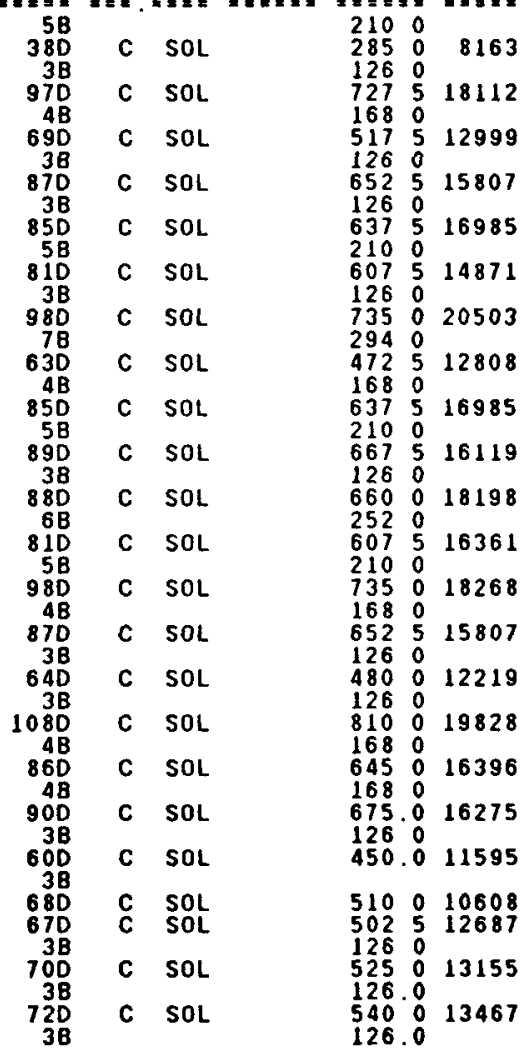


PNO 11 UNC DOS - WASTE SHIPMENT REPORT - PROTECTIVE CLOTHING

RID $36286 \mathrm{C}$

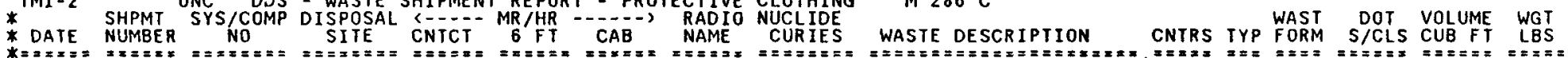
DRUMS CONTAINERS $\begin{array}{ll}\text { VOLUME. CU FT } & =199.56200 \% \\ \text { WE IGHT. LBS } & =3,426.656 *\end{array}$ $\begin{array}{llc}\text { BOXES CONTAINERS } & & 516 \\ \text { ACTIVITY CURIES } & = & 0 * \\ \text { VOLUME. CU FT } & = & 19.2960^{00 *} \\ \text { WEIGHT. LBS } & = & 00\end{array}$ $\begin{array}{ll}\text { ALL CONTAINERS } & =26.635 \\ \text { ACTIVITY CURIES } & = \\ \text { VOLUME. CUFT } & =218.83825720 *\end{array}$ $\begin{array}{ll}\text { VOLUME. CUFT } & =218.8380^{\circ} \\ \text { WEIGHT: LBS } & =3.426 .6560^{\circ} \\ & \text { END REPORT }\end{array}$ 
4.0 COMPUTER REPORTS

4.4 TMI-2 Radroactive Waste Notes 


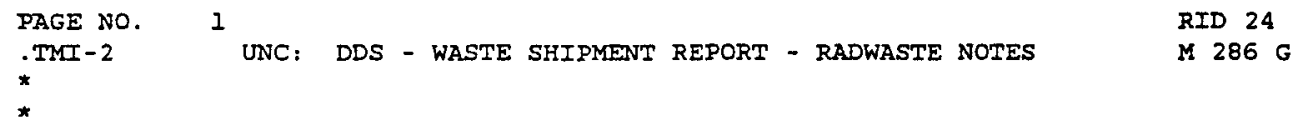

THIS REPORT IS A WORKING DOCUMENT AND WILI BE UPDATED PERIODICALIY.

NOTES:

-....

1. WASTE DISPOSAI SITES

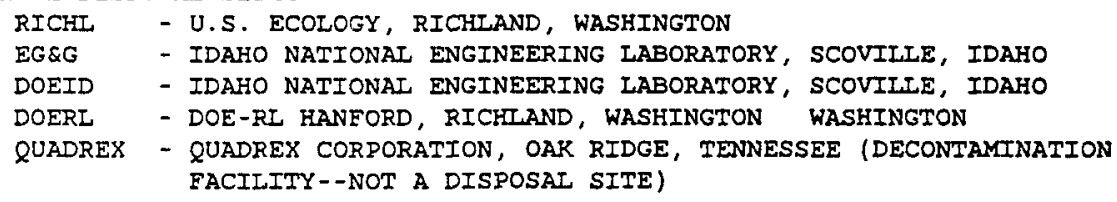

2. RADIONUCLIDES REMOVED EROM ACCIDENT WATER DURING PROCESSING THROUGH THE SUBMERGED DEMINERAIIZER SYSTEM (SDS), THE EPICOR SYSTEM PREFIITERS (PF) AND THE EPICOR SYSTEM DEMINERALIZERS (DE, DS, F, K AND 2K) ARE SHOWN AS AVERAGE WEIGKT PERCENTAGES IN THE FOLLOWING TABLE: (NS - NOT SIGNIFICANT) THE REMAINING INSIGNIFICANT PERCENTAGES CONSIST OF MINUTE AMOUNTS OF OTHER FISSION PRODUCTS. IT IS ASSUMED THAT AII WASTES CONTAIN THE SAME RADIONUCLIDE CONCENTRATIONS AS ACCIDENT WATER.

\begin{tabular}{|c|c|c|c|c|c|c|c|}
\hline \multicolumn{2}{|c|}{ NUCLIDE } & SDS & PF & DF & DS & $\mathbf{F}$ & $K \& 2 \mathrm{~K}$ \\
\hline \multirow{2}{*}{\multicolumn{2}{|c|}{$--\cdots--$}} & $\cdots$ & -- & -- & -- & $\cdots$ & $---\cdot-$ \\
\hline & & $\div$ & $\div$ & $\%$ & $\%$ & $\div$ & $\div$ \\
\hline $\mathrm{CR}$ & 51 & NS & NS & NS & 0.04 & NS & 0.12 \\
\hline $\mathrm{MN}$ & 54 & NS & 0.02 & NS & NS & 0.01 & 0.08 \\
\hline $\mathrm{CO}$ & 58 & NS & NS & NS & NS & 0.04 & NS \\
\hline $\mathrm{co}$ & 60 & 0.01 & 0.01 & NS & 0.05 & 0.13 & 0.08 \\
\hline SR & 90 & 1.85 & 2.71 & 7.65 & 30.97 & 29.36 & 32.45 \\
\hline$Y$ & 90 & 1.85 & 2.71 & 7.65 & 30.97 & 29.36 & 32.45 \\
\hline RU & 103 & NS & NS & NS & 0.01 & NS & NS \\
\hline RH & $103 \mathrm{M}$ & NS & NS & NS & 0.01 & NS & NS \\
\hline RU & 106 & 0.26 & 0.91 & 1.23 & 1.25 & 0.69 & 1.03 \\
\hline RH & 106 & 0.26 & 0.91 & 1.23 & 1.25 & 0.69 & 1.03 \\
\hline AG & 210 & NS & 0.03 & 0.10 & 0.01 & NS & NS \\
\hline SN & 113 & NS & NS & NS & 0.04 & NS & NS \\
\hline$I N$ & 113 & NS & NS & NS & 0.04 & NS & NS \\
\hline$S B$ & 125 & 0.34 & 0.05 & 0.32 & 0.65 & 18.48 & 20.06 \\
\hline$T E$ & $125 \mathrm{M}$ & 0.08 & 0.02 & 0.07 & 0.11 & 4.25 & 4.62 \\
\hline $\mathrm{Cs}$ & 134 & 3.90 & 4.54 & 5.07 & 2.28 & 0.79 & 0.34 \\
\hline $\mathrm{CS}$ & 137 & 46.81 & 45.21 & 39.28 & 15.97 & 7.08 & 2.93 \\
\hline$B A$ & $137 \mathrm{M}$ & 44.29 & 42.77 & 37.07 & 15.10 & 6.69 & 2.77 \\
\hline$C E$ & 144 & 0.17 & NS & 0.18 & 0.59 & 1.21 & 1.02 \\
\hline \multirow[t]{2}{*}{$\mathrm{PR}$} & 144 & 0.17 & NS & 0.18 & 0.59 & 1.21 & 1.02 \\
\hline & & ---- & $-\cdots$ & ---- & ---- & ---- & $--\cdot-$ \\
\hline \multicolumn{2}{|c|}{ TOTAL } & 99.99 & 99.89 & 99.93 & 99.93 & 99.99 & 100 \\
\hline
\end{tabular}


PAGE NO. .TIII - 2

2

UNC: DDS - WASTE SHIPMENT REPORT - RADWASTE NOTES
RID 24

M $286 \mathrm{G}$

*

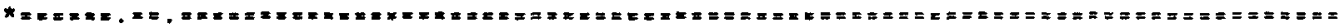

3. CONTAINERS (ONTRS) - B = BOX; D = DRUM; C $=$ CASK; I = IINER; $T=$ TANK

4. TYPE - A = ACTIVATION, $C=$ CONTAMINATION

5. DOT S/CIS - ISA = LOW SPECIFIC ACTIVITY; IQ = LARGE QUANTITY

6. NEG - NEGLIGIBLE (USUALLY LESS THAN ONE MILIICURIE)

7. DNA - DATA NOT AVAILABLE 


\subsection{COMPUTER REPORTS}

4.5 Waste Shipment Report - Radioactive Waste 
PNO 1 UNC DDS - WASTE SHIPMENT REPORT - RADIOACTIVE WASTE RID $37286 \mathrm{C}$

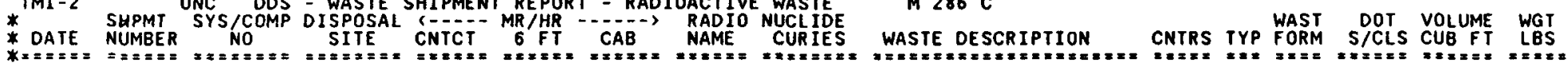

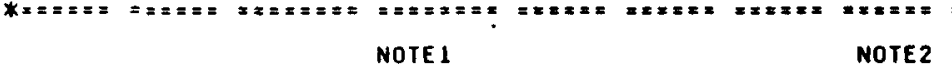

$\begin{array}{ll}790409 & 79034 \\ 790409 & 79035\end{array}$

790409
790419 79035

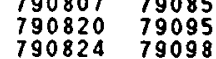

$\begin{array}{ll}790824 & 79098 \\ 790827 & 79101\end{array}$

*

$\omega$

RICHL

RICHL
RICHL
RICHL
RICHL
RICHL
RICHL
RICHL

$\begin{array}{lllll}0 & 10 & 10 & 10 & \text { DNA } \\ 0 & 30 & 20 & 10 & \text { DNA } \\ 1 & 30 & 0 & 60 & \text { DNA }\end{array}$

$\begin{array}{rrrrrr}30 & 30 & 0 & 60 & \text { DNA } & \\ 30 & 00 & 1 & 50 & 0 & 50 \\ 30 & 00 & 1 & 50 & 0 & 05\end{array}$

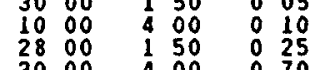

$\begin{array}{llllll}\text { RICHL } & 1350 & 13 & 30 & 0 & 25\end{array}$

$790830 \quad 79108$
790831 79111

790904
790907 79112
791001
791002 79125

$791129 \quad 79149$

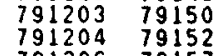

$791206 \quad 79157$

$791207 \quad 79161$

791210
791211 79163

800108
800123 80002

$\begin{array}{ll}800206 & 80011 \\ 800313 & 80016\end{array}$

80040280029

8004168003

800605
800606
80049

80062580060

80063080040

$\begin{array}{ll}800707 & 80071 \\ 800707 & 80063\end{array}$

80070980067

80071180070

$\begin{array}{ll}800721 & 80079 \\ 800722 & 80080\end{array}$

* $800722 \quad 80080$

* 80073180081

$\begin{array}{ll}800731 & 80086 \\ 800801 & 80085\end{array}$
1300000 SOLIDIF IED WASTE

670000 SOLIDIF IED WASTE

340000 NON-COMPACTED TRASH

30000 NON-COMPACTED TRASH

1040000 NON-COMPACTED TRASH

20000
0
20000
0

60000 NON-COMPACTED TRASH

020000 NON-COMPACTED TRASH

30000 NON-COMPACTED TRASH

040000 NON-COMPACTED IRASH

100000 NON-COMPACIED IRASH

20000 NON-COMPACTED TRASH

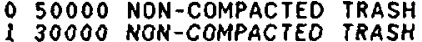

20000 NON-COMPACTED TRASH

10000 COMPACTED TRASH

80000 COMPACTED TRASH

70000
3
20000

460000 RESIN LINER
$10-12$
100000 RESIN LINER
$8-7$
80000 RESIN IINER P-12

50000 RESIN LINER P-12
560000 SOLIDIFIED WASTE

60000 RESIN LINER D-20

40000 NON-COMPACTED TRASH

260000 RESIN LINER D-18

410000 RESIN LINER D-13

280000 RESIN LINER P-9

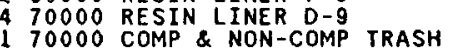

170000 COMP \& NON-COMP TRASH

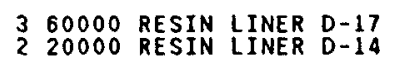

NOTE3

NOTE5

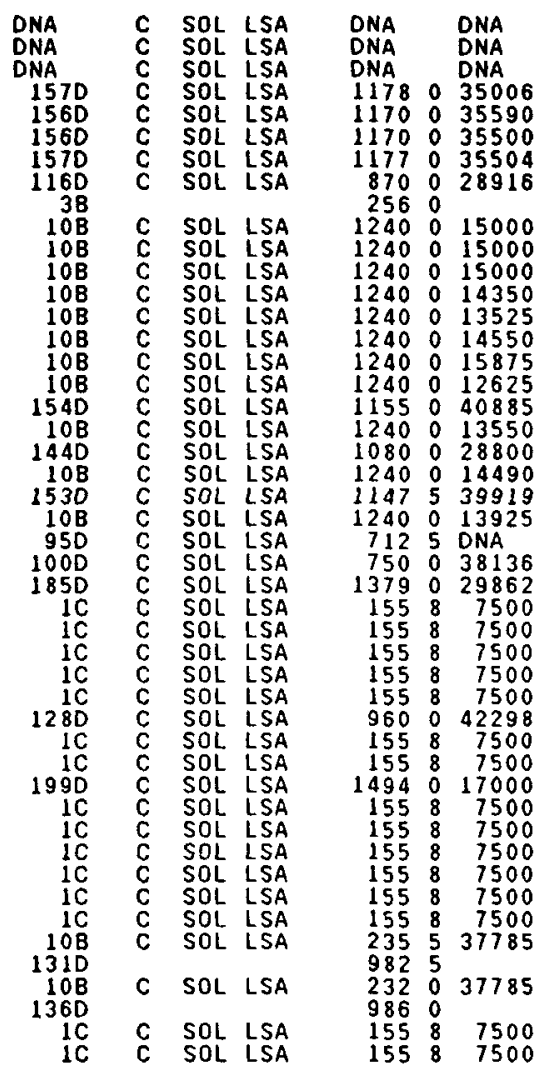


DATE 100187 PAGE

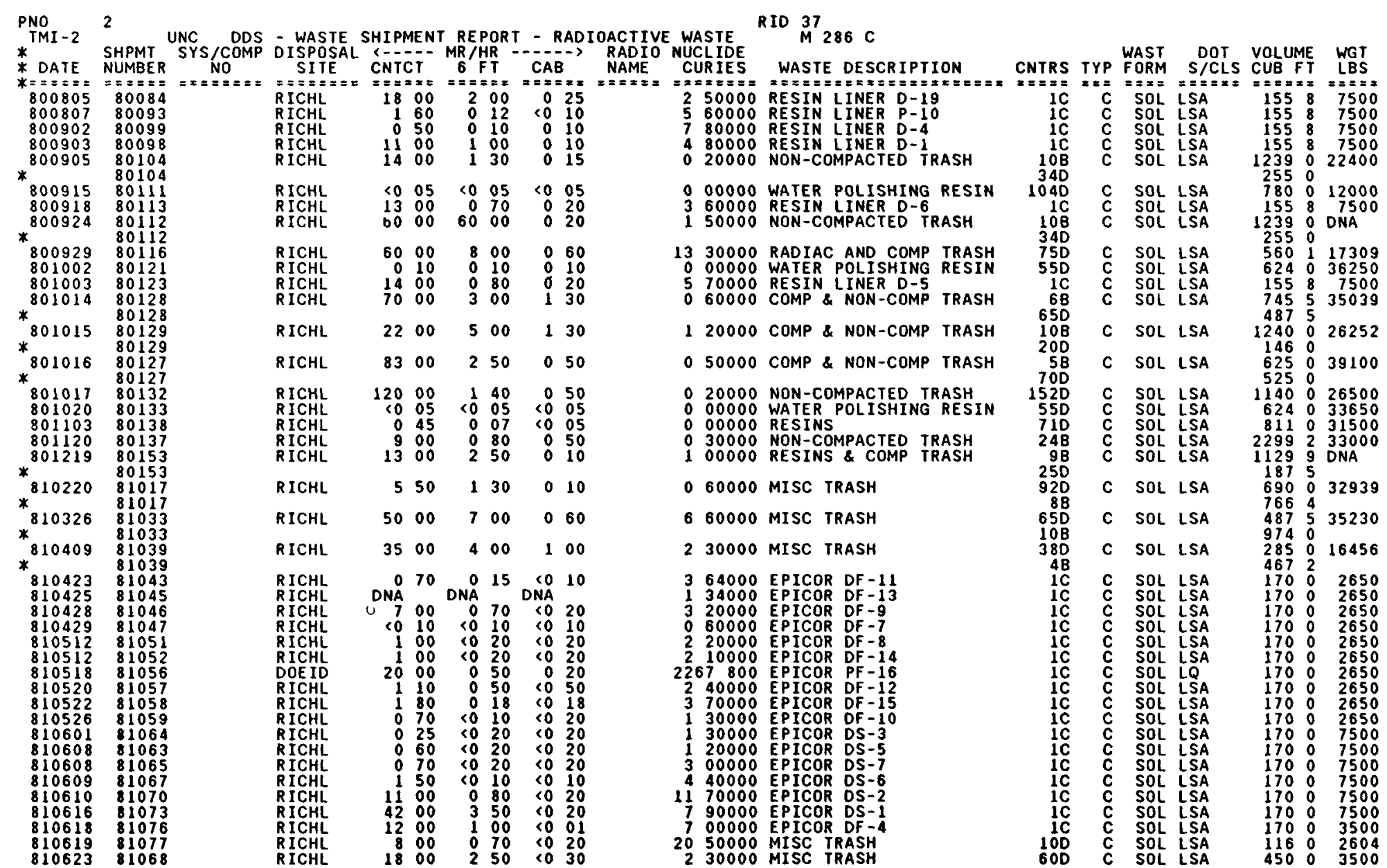


DATE 100187 PAGE

PNO 3 TMI-2 3 UNC DDS - WASTE SHIPMENT REPORT - RADIOACTIVE WASTE RID $37286 \mathrm{C}$

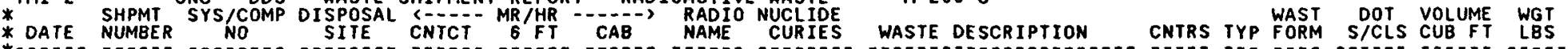

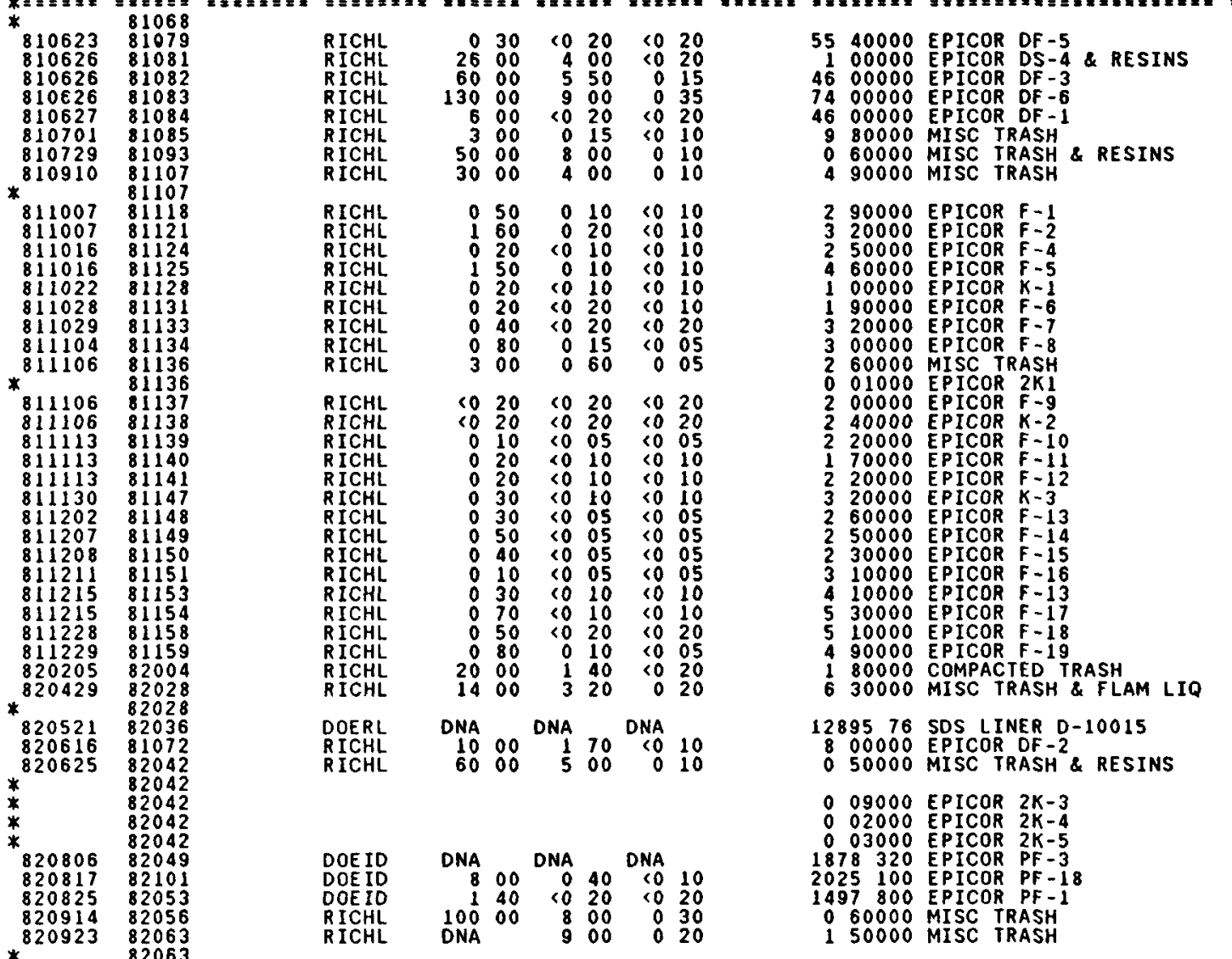

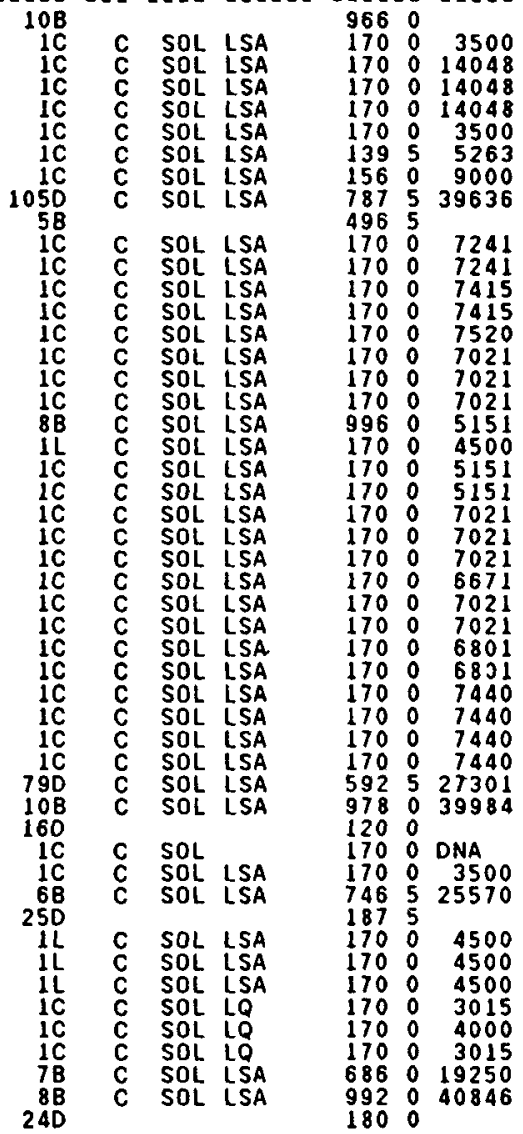


DATE 100187 PAGE

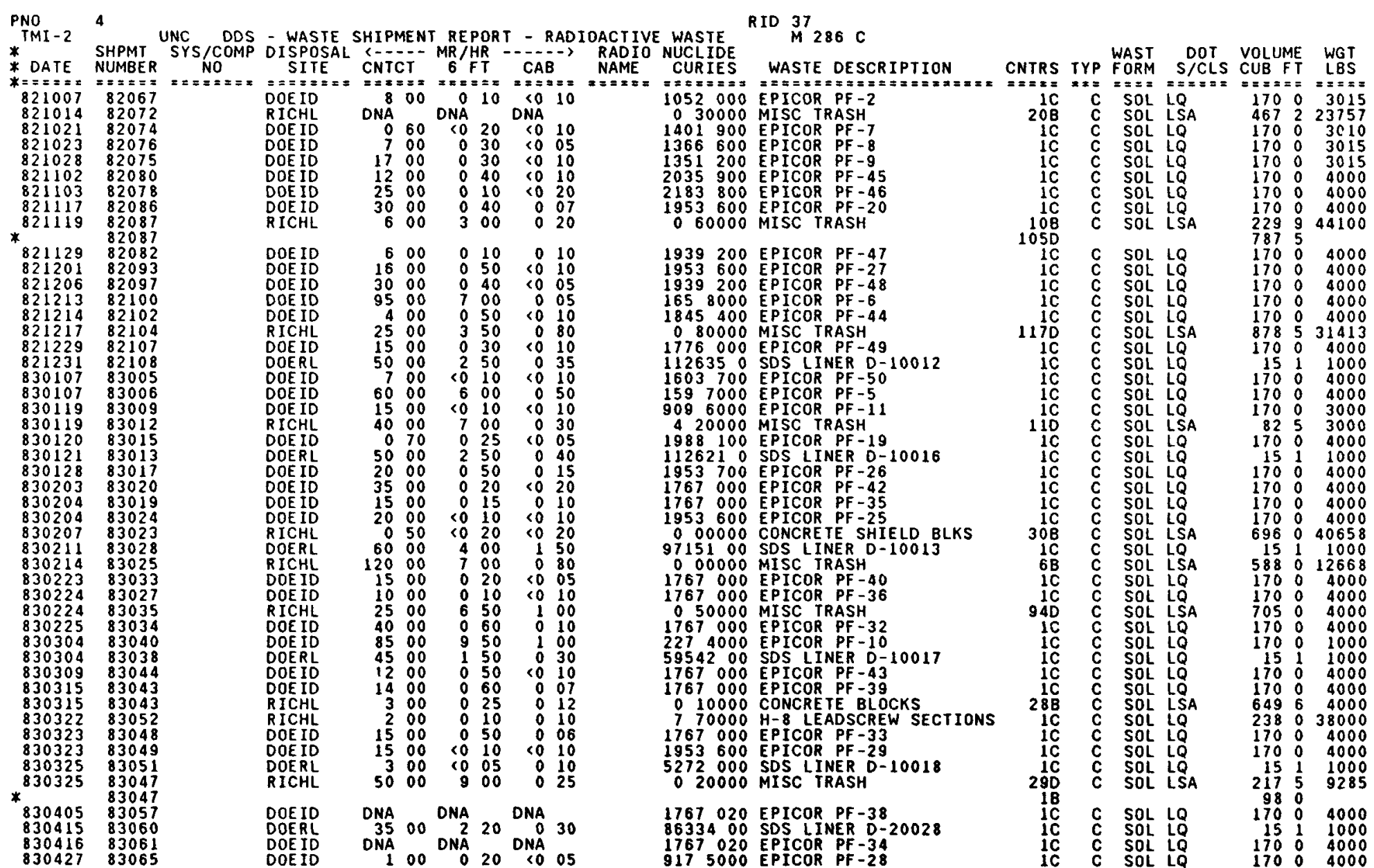




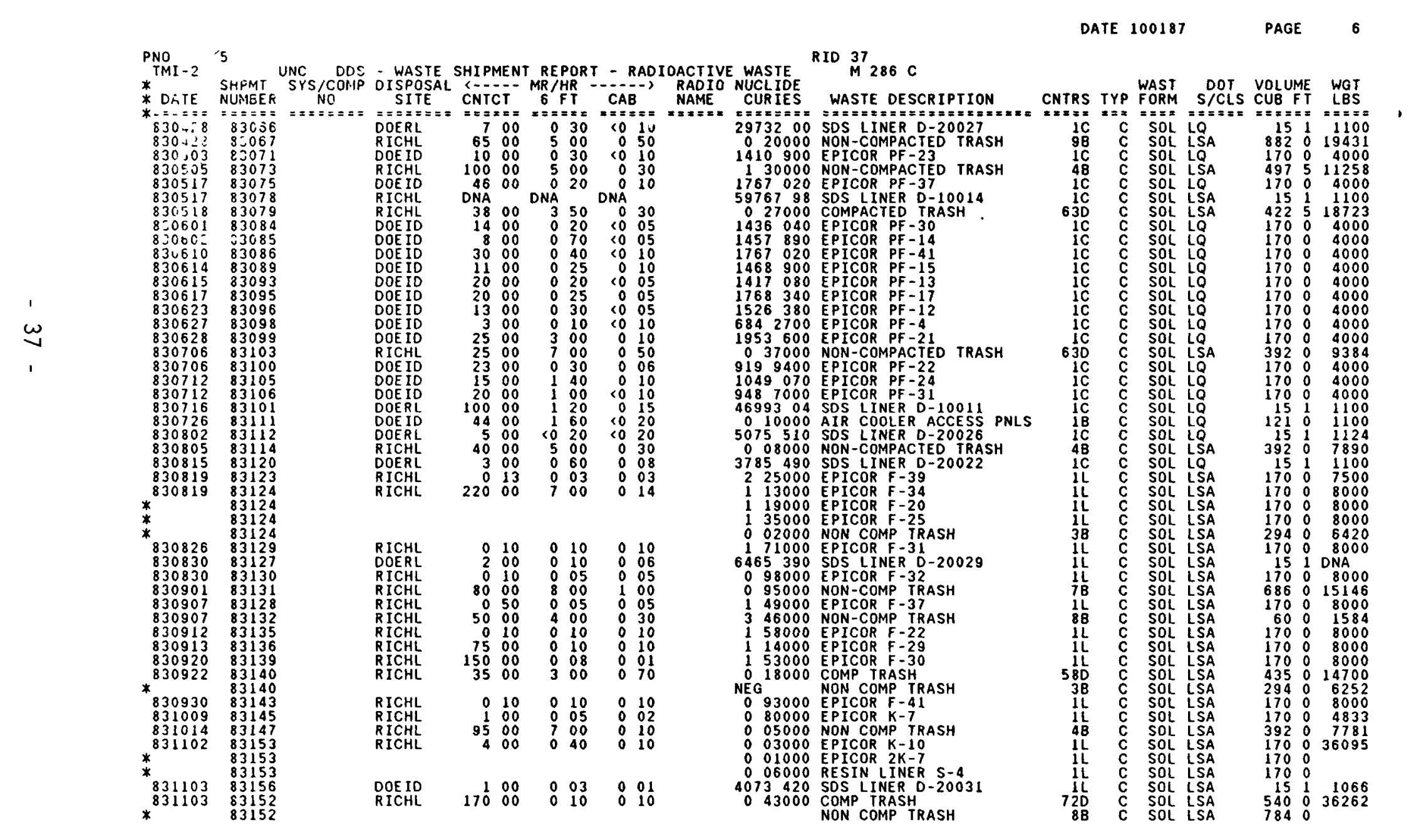




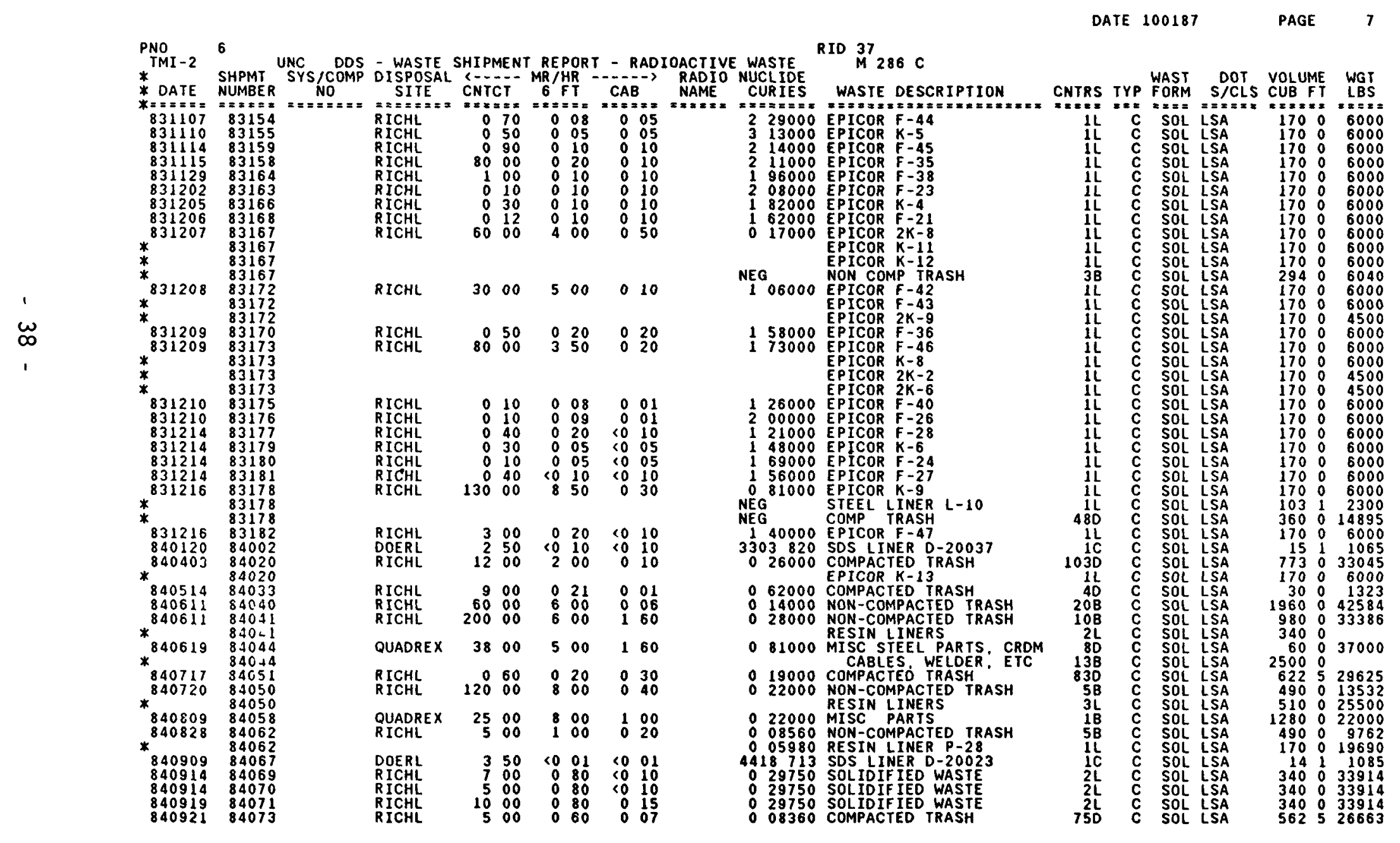


DATE 100187 PAGE

PNO 7 TMI-2 7 UNC DDS - WASTE SHIPMENT REPORT - RADIOACTIVE WASTE RID $37286 \mathrm{C}$

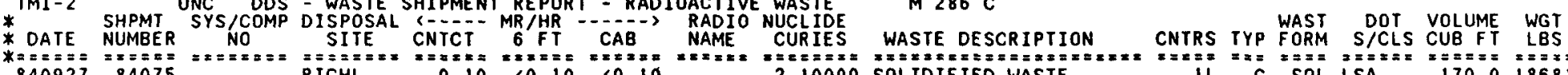

$840927 \quad 84075$

84101284084

* 841028.84083 sis

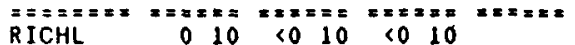

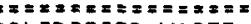
CNTRS TYP FORM S/CLS CUB FT LBS 84102284087

$841105 \quad 84088$
$* \quad 84088$

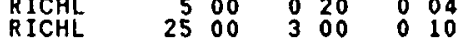
$\begin{array}{lrrrrrr}\text { RICHL } & 1 & 00 & <0 & 20 & <0 & 20 \\ \text { RICHL } & 100 & 00 & 5 & 00 & 0 & 20\end{array}$

$\begin{array}{lrlllll}\text { DOERL } & 0 & 16 & 0 & 03 & 0 & 02 \\ \text { RICHL } & 20 & 00 & 1 & 50 & 0 & 10\end{array}$

$\begin{array}{lrrrrrr}R & 20 & 00 & 1 & 50 & 0 & 10 \\ \text { DOERL } & 2 & 00 & 0 & 04 & 0 & 01 \\ R I C H L & 1 & 20 & <0 & 10 & 10 & 10\end{array}$

RICHL $2100010<0$

$\begin{array}{lllllll}\text { RICHL } & 0 & 30 & <0 & 10 & 0 & 02 \\ \text { RICHL } & 10 & 10 \\ \text { RICHL } & 0 & 60 & <0 & 20 & 10 & 10\end{array}$

$\begin{array}{lrrrrrr}R I C H L & 0 & 30 & <0 & 10 & <0 & 10 \\ \text { RICHL } & 30 & 00 & 3 & 00 & <0 & 10\end{array}$

$\begin{array}{lllllll}\text { RICHL } & 30 & 00 & 3 & 00 & <0 & 10 \\ \text { RICHL } & 15 & 00 & 0 & 60 & <0 & 20\end{array}$

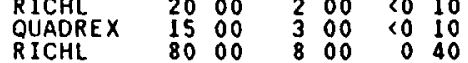

$\begin{array}{lllllll}\text { RICHL } & 0 & 10 & <0 & 10 & 10 & 20 \\ \text { DOERL } & <0 & 20 & <0 & 20 & <0 & 10\end{array}$

QUADREX $1500 \quad 200 \quad 008$

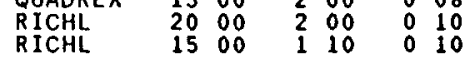

QUADREX DNA DNA DNA

QUADREX $2100,300 \quad 0000$

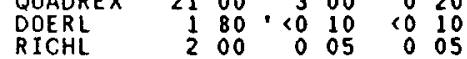

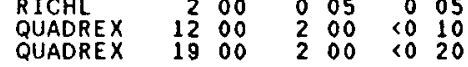

$\begin{array}{lllllll}\text { EGEG } & 70 & 00 & 3 & 00 & 0 & 60 \\ \text { EG\&G } & 20 & 00 & 3 & 00 & 0 & 60\end{array}$

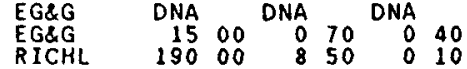

RICHL

$\begin{array}{rrrrr}\text { DNA } & \text { DNA } & \text { DNA } \\ 150 & 00 & 00 & 0 \\ 60 & 00 & 4 & 00 & 20 \\ 6 & 0 & 15\end{array}$

RICHL

$\begin{array}{rrrrrrr}\text { DNA } & \text { DNA } & & \text { DNA } & \\ <0 & 10 & <0 & 10 & <0 & 10 \\ 0 & 40 & 0 & 20 & 0 & 20 \\ 3 & 20 & 0 & 08 & 0 & 07\end{array}$

210000 SOLIDIFIED WASEE
70 . 49900 SOL IDIFIED WASTE-RESIN
03700 POLISHNG REST LINERS

NON-COMPACTED TRASH

64000 SOLIDIFIED WASTE -
044400 COMPATED

167000 DEWATERED RESIN

0 10300 NON-COMPACTED TRASH

080900 SOS TNER O-2002

50000 FL50 HIC $003 \mathrm{JF}$

$\begin{array}{lll}134000 \mathrm{FL} 50 \mathrm{HIC} & 005 \mathrm{JF}\end{array}$

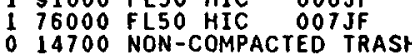

14700 NON-COMACTED
0
00100
0

43400 COMPAC

150000 NON-COMPACTED TRASH

326000 K-15 LNNER 20033

O 14830 SCRAP METAL

0 18800 COMPACTED TRASH

010300 2K-10 RESIN LINER
NON-COMPACALD TRASH

- 11900 SCRAP METAL

78700 MISC STEEL \& EQUIP

4415204 SDS LINER U-00009

9 93900 हPTCR

09760 SCRAP STEEL/ACID MIX

038000 STEEL TANK

38000 STEEL TANK
38000 STEEL TANK

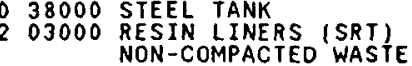

N6100 NONCOMPACTED WASTE

0 27700 NON-COMPACTED WASTE

N8700 CON-COMPACCED WASTE

038700 COMPACTED WASTE

1350000 LINR (HITMAN)

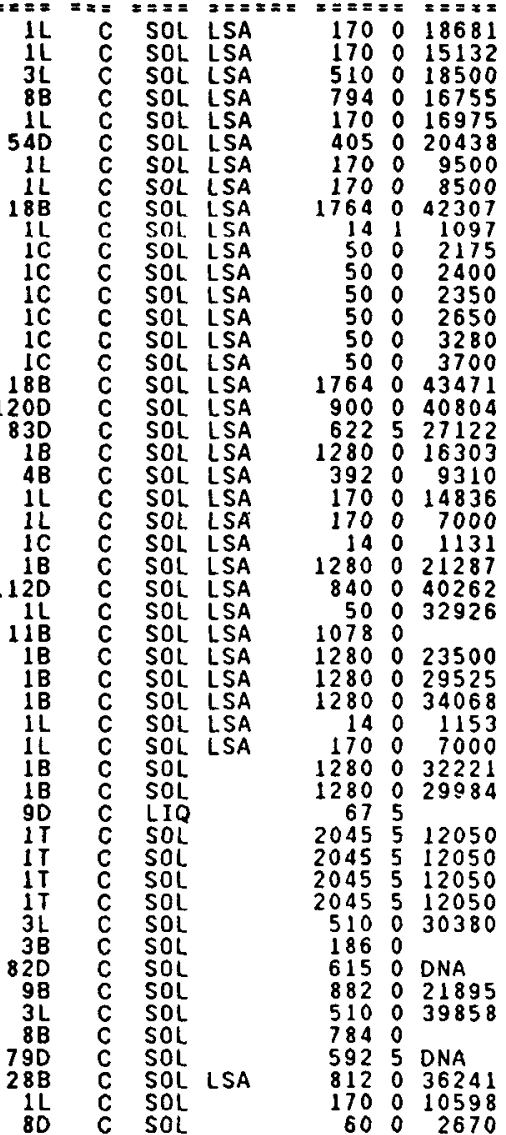




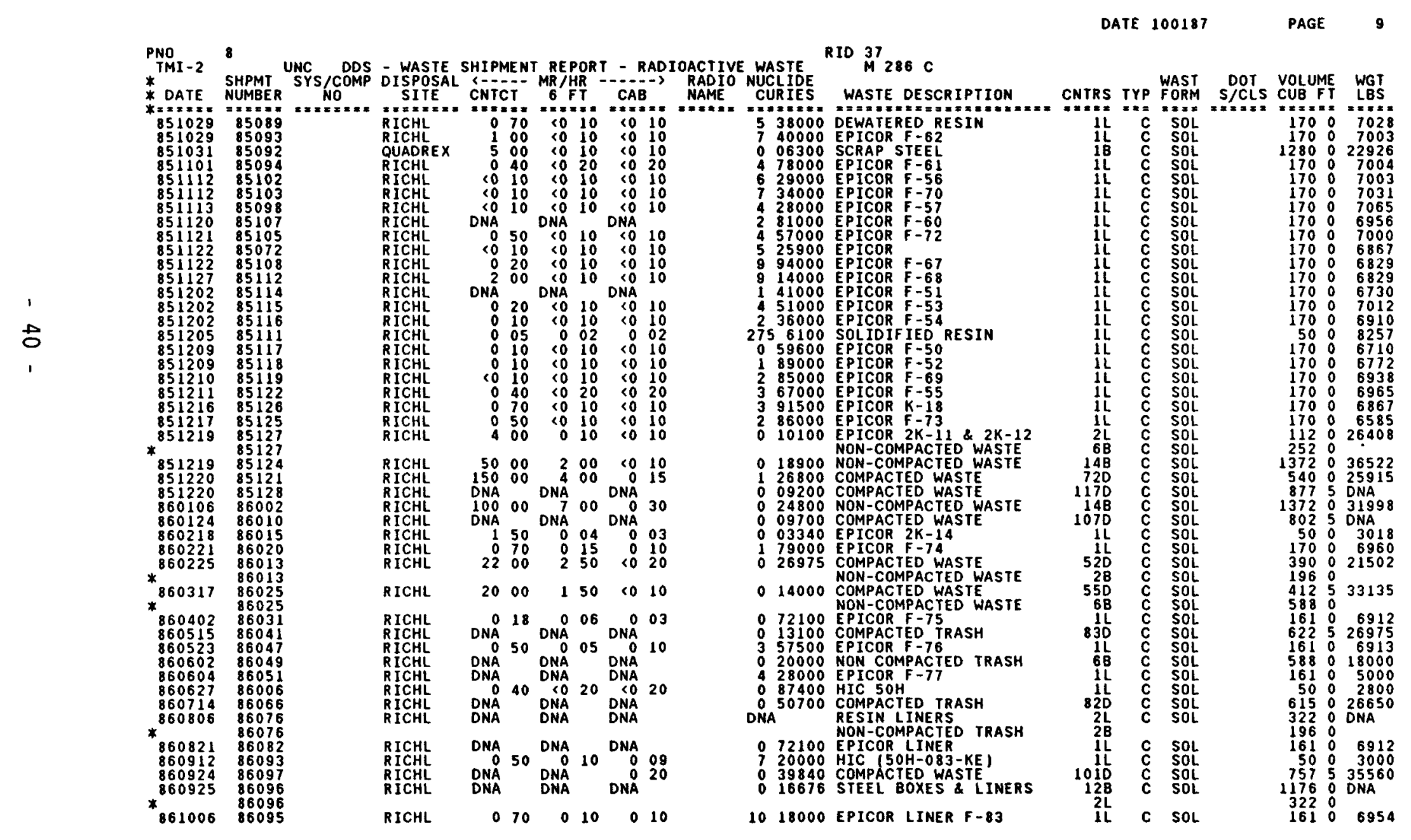




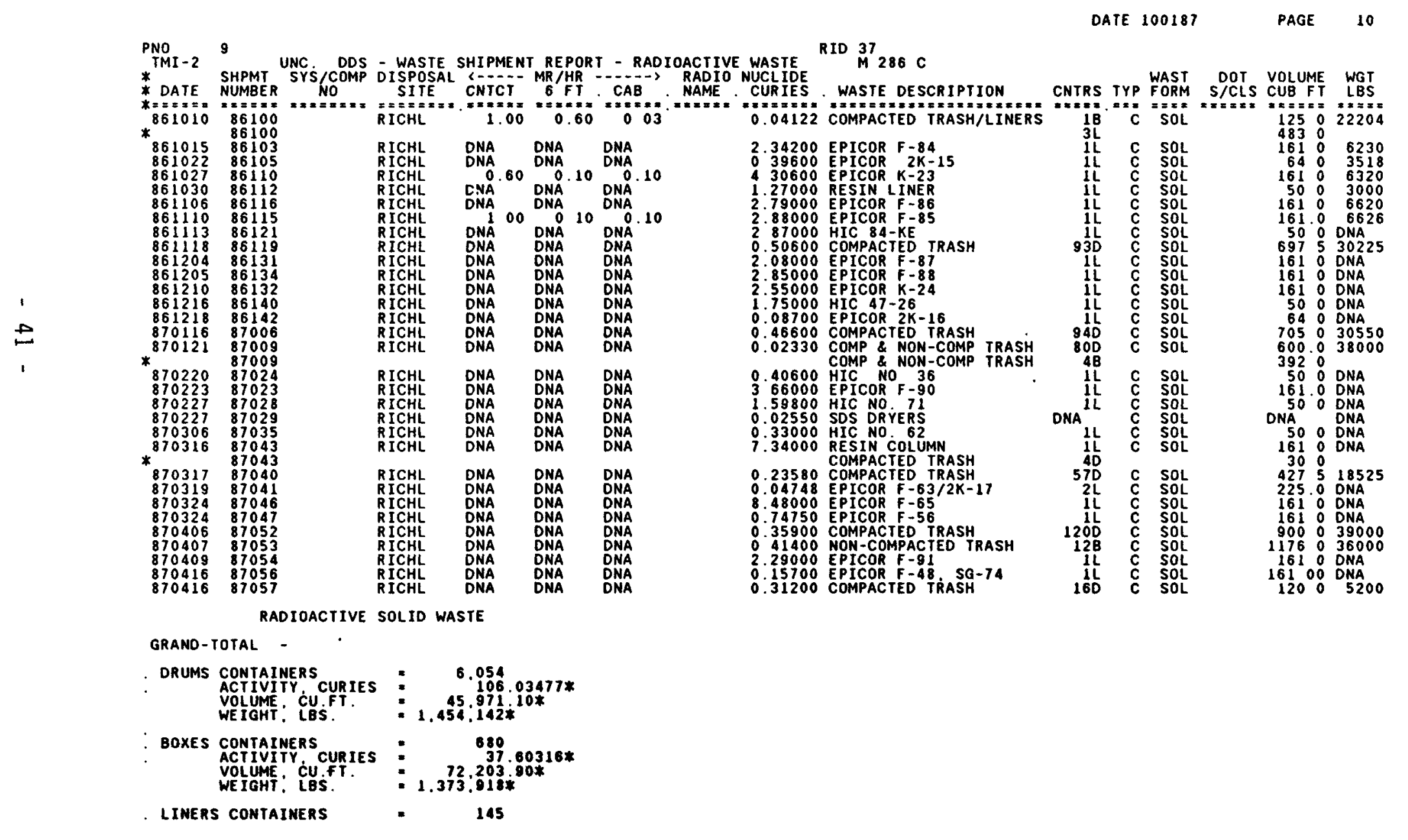




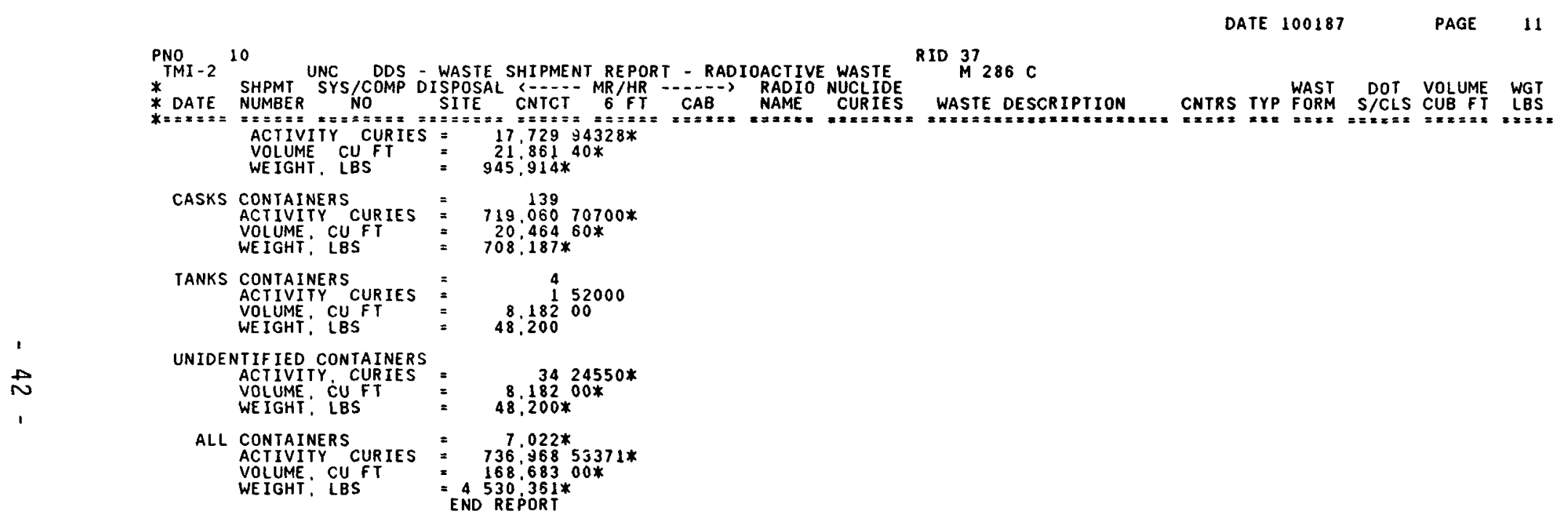




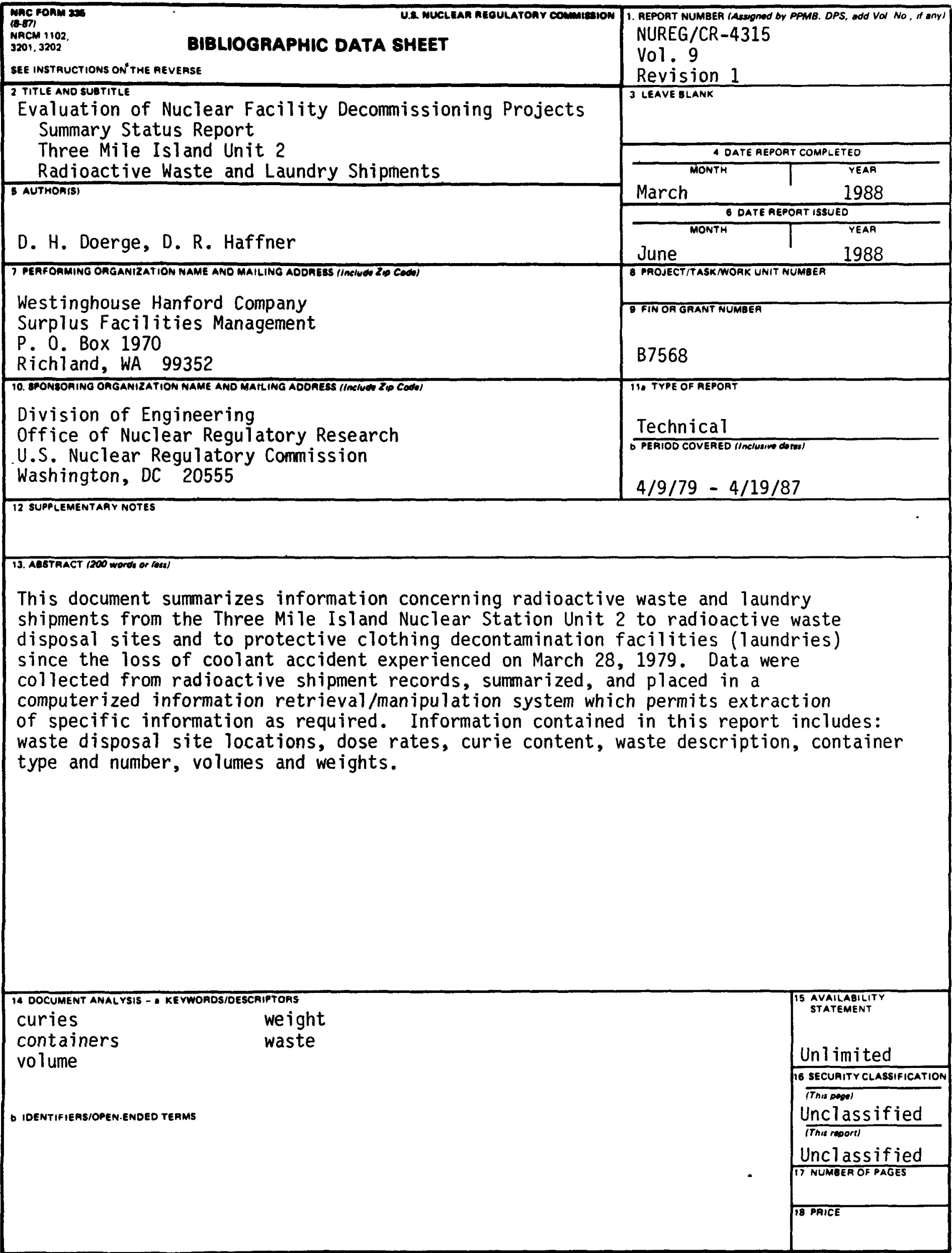




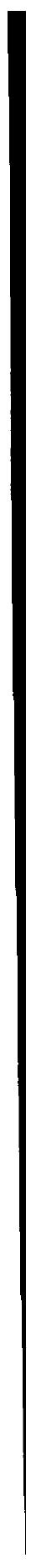




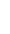

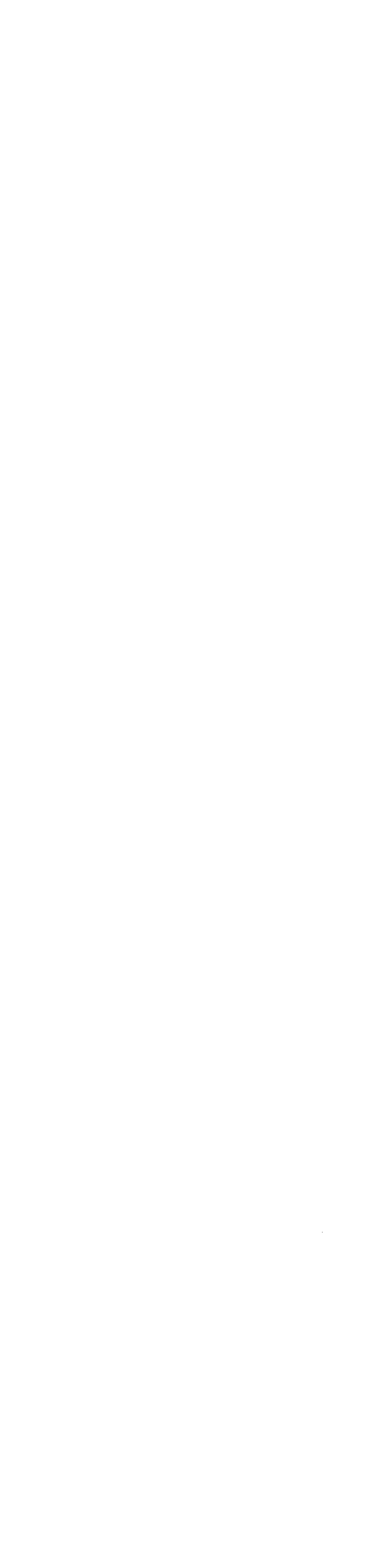




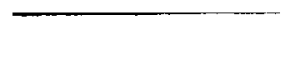




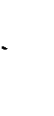


UNITED STATES

NUCLEAR REGULATORY COMMISSION

WASHINGTON, D.C. 20555

OFFICIAL BUSINESS

PENALTY FOR PRIVATE USE, $\$ 300$
SPECIAL FOUATH-CLASS RATE

POSTAGE E FEES PAID

USNAC.

PERMIT No. G-67 